\title{
ARTICLES
}

\section{THE SOUND AND FURY OF CARRIED INTEREST REFORM}

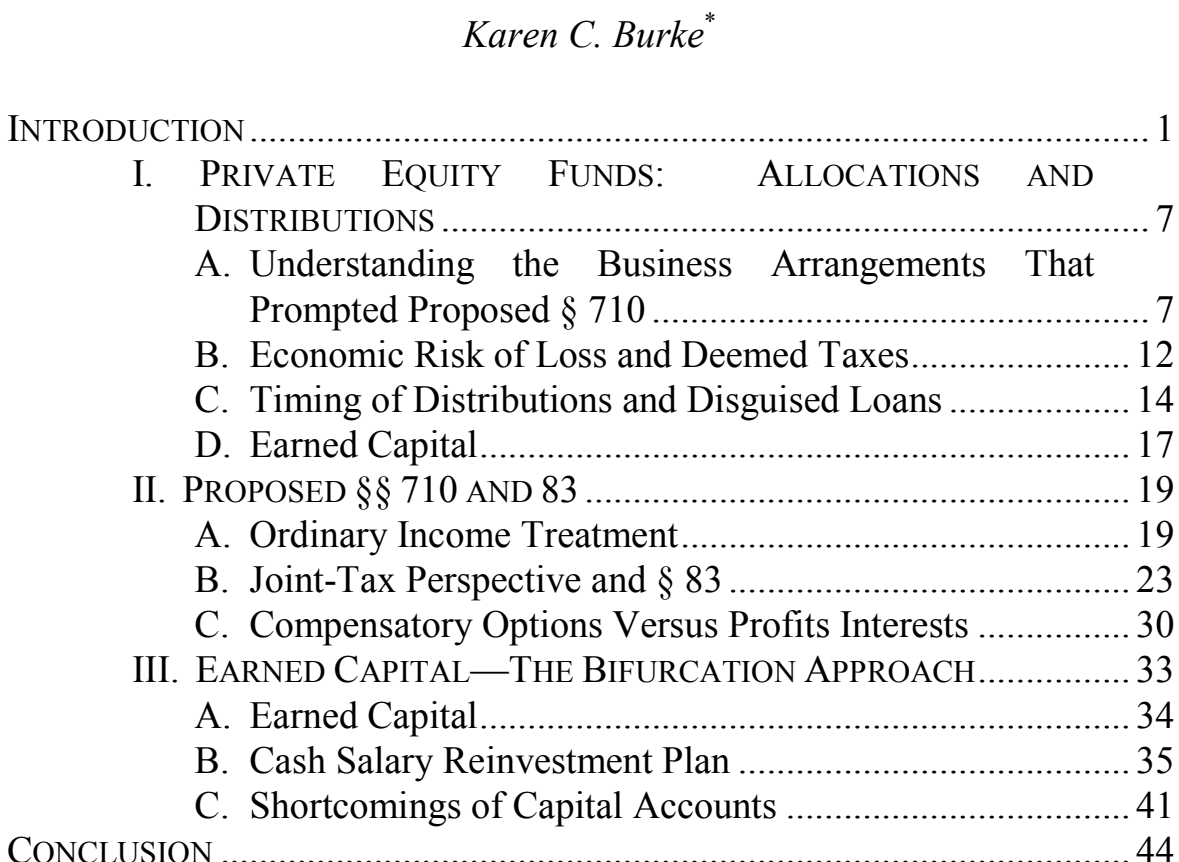

\section{INTRODUCTION}

Of all the proposals advanced in recent years to reform Subchapter $\mathrm{K}$, the part of the Internal Revenue Code ("IRC" or "Code") governing partnership tax, perhaps none has generated more acrimony and confusion

\footnotetext{
* Warren Distinguished Professor of Law, University of San Diego School of Law. The author wishes to thank especially Mark Gergen, Michael Schler, David Walker, and George Yin for helping to clarify her thinking about the carried interest problem. The author acknowledges generous research support from the University of San Diego School of Law. This research was not supported by funding from any outside source.
} 
than the pending carried interest legislation contained in proposed $\S 710{ }^{1}$ While reformers have framed the issue of taxing the compensatory portion of a service partner's return as ordinary income in terms of distributive justice, critics have been quick to invoke the rhetoric of class warfare to fend off reform. ${ }^{2}$ In the most elementary terms, the carried interest legislation would tax some (but not all) of a service partner's share of partnership profits as ordinary income. ${ }^{3}$ Even at this basic level, however, the contours of the proposed legislation are ambiguous. Indeed, the reform is sometimes misdescribed as taxing "distributions" rather than "distributive shares" as ordinary income, a distinction that is fundamental. ${ }^{4}$ Moreover, the precise tax advantage of carried interest arrangements depends crucially on whether one adopts a "joint-tax" perspective or focuses more narrowly

1. Unless otherwise indicated, all statutory references to the Internal Revenue Code (I.R.C.) are to the I.R.C. as currently in effect. References to Proposed $\S 710$ (Prop. $\S 710$ ) refer to the version introduced by Representative Sander Levin in April 2009. H.R. 1935, 111th Cong. (2009) [hereinafter Levin Bill]. See also Tax Extenders Act of 2009, H.R. 4213, 111th Cong. (2009). The current legislation is similar to the Alternative Minimum Tax Relief Act of 2008, H.R. 6275, 110th Cong. (2008). The Senate Finance Committee held relevant hearings on July 11, 2007, and July 31, 2007. S. Finance Comm., Hearing on Carried Interest (2007) [hereinafter Senate Hearings], available at http://finance.senate.gov/sitepages/hearing071107.htm (Part I) and http://finance.senate.gov/sitepages/hearing073107.htm (Part II) (last visited Feb. 14, 2010). The House Ways and Means Committee held a hearing on Sept. 6, 2007. H. Ways \& Means Comm., Hearing on Fair and Equitable Tax Policy for America's Working Families (2007) [hereinafter House Hearing], available at http://waysandmeans.house.gov/Hearings/transcript.aspx?NewsID=10305 (last visited Feb. $14,2010)$.

2. See, e.g., Victor Fleischer, Two and Twenty: Taxing Partnership Profits in Private Equity Funds, 83 N.Y.U. L. REV. 1, 5 (2008) ("Distributive justice, of course, is also a concern."); House Hearing, supra note 1 (Statement of Victor Fleischer), at 7 ("A few professors have been retained by the private equity industry to argue for the status quo; there may be a handful of others who independently support the status quo, but they are few and far between."); Howard E. Abrams, Taxation of Carried Interests: The Reform That Did Not Happen, 40 Loy. U. CHI. L.J. 197, 227 (2009) ("Professor Fleischer framed the carried interest issue largely in class-warfare terms, with private equity and hedge managers as the bad guys.").

3. The proposed reform bears a superficial resemblance to proposals set forth by Mark Gergen nearly two decades ago that would tax service partners on compensation when they receive disproportionate allocations relative to their capital account balances. See Mark P. Gergen, Reforming Subchapter K: Compensating Service Partners, 48 TAX L. Rev. 69, 105 (1992) (claiming that the proposed system would be "very much like subchapter S").

4. See Fleischer, supra note 2, at 59 (describing the legislative proposal as "treat[ing] carried interest distributions as ordinary income"). A partner is taxed on his distributive share of partnership income when realized at the partnership level, whether or not distributed. See I.R.C. $§ 702$ (a) (2009) (inclusion of distributive share); $c f$. I.R.C. $\S 731$ (2009) (taxing distributions). To the extent that earnings are not currently distributed, accounting for "reinvested" implicit salary greatly complicates the actual operation of the proposed legislation. 
on the service partner's opportunity for deferral and conversion. ${ }^{5}$ Apart from the merits of carried interest legislation, there is also considerable dispute over whether such reform is likely to raise significant amounts of revenue. ${ }^{6}$

The Administration's budget proposals for fiscal year 2010 contain a carried interest provision that appears to adopt the general framework of H.R. 1935 (the Levin Bill) introduced in 2009. ${ }^{7}$ Under this approach, a service partner's distributive share of income would be recharacterized as ordinary income, regardless of whether such income would otherwise be treated as lower-taxed capital gain or dividend income at the partnership level. ${ }^{8}$ The proposal would also treat gain on sale of a service partner's interest as ordinary income, subject to certain exceptions. ${ }^{9}$ As the reason for the change, the budget proposal refers to the "unfair and inefficient tax preference" resulting from allowing service partners to "receive capital gains treatment on labor income," particularly in view of the "recent explosion of activity among large private equity firms." 10 In its present form, the Levin bill reflects key recommendations of the partnership tax bar which has intensely scrutinized the technical operation of the carried

5. The leading article applying a joint-tax perspective in the context of partnership profits interests is Chris William Sanchirico, The Tax Advantage of Paying Private Equity Fund Managers with Profit Shares: What Is It? Why Is It Bad?, 75 U. CHI. L. REv. 1071 (2008). Other commentators have employed a similar joint-tax perspective in the corporate area. See generally Michael S. Knoll, The Section 83(b) Election for Restricted Stock: A Joint Tax Perspective, 59 SMU L. REV. 721 (2006); David I. Walker, Is Equity Compensation Tax Advantaged?, 84 B.U. L. REv. 695 (2004).

6. See, e.g., Michael S. Knoll, The Taxation of Private Equity Carried Interests: Estimating the Revenue Effects of Taxing Profit Interests as Ordinary Income, 50 WM. \& MARY L. REV. 115, 161 (2008) (concluding that, even in the absence of "alternative structures to undo the effect of any reform," carried interest legislation is likely to raise “relatively little revenue"). See also U.S. DeP'T OF THE TREASURY, GENERAL EXPLANATIONS of the Administration's Fiscal Year 2010 Revenue Proposals 128 (May 2009) (Table 1) [hereinafter Greenbook]. This Article does not discuss the plethora of anti-abuse rules intended to prevent circumvention of the proposed legislation.

7. See Greenbook, supra note 6, at 23-24. Unlike the Levin bill which specifically targets investment service partnerships, the Administration's proposal would apparently apply broadly to all service partnerships. See STAFF OF JOINT COMM. ON TAX'N, Description of the Revenue Provisions Contained in the President's Fiscal Year 2010 Proposal 120-22 (Sept. 2009) (JCS-2-09) (noting issues related to the "complexity, administrability and scope" of the Administration's broader proposal).

8. See Greenbook, supra note 6 , at 23 . A profits share taxed as ordinary income to the service partner would also be subject to self-employment tax. See id. To prevent circumvention of the legislation through use of separate entities, the budget proposal would treat income or gain from a "disqualified interest" as ordinary income. See id. at 24.

9. See id. at 23 (treating gain on sale as ordinary income to the extent that such gain is not attributable to invested capital).

10. Id. 
interest proposals. ${ }^{11}$ By contrast, academic proponents of carried interest legislation have generally suggested that the technical problems are solvable and need not impede reform. ${ }^{12}$ The partnership tax bar's recommendations would add flexibility and electivity while making the proposed legislation considerably more complex. The emerging consensus seems to be that the current legislation has "the potential to be workable" if only Congress heeds the partnership tax bar's recommendations to remedy existing defects. ${ }^{13}$

In view of the often highly-charged and polemical nature of the carried interest debate, it is important to understand the most significant policy and technical choices underlying the current legislation. Despite the intuitive appeal of taxing service partners at ordinary income rates on labor income, the case for reform is much more nuanced and the proposed solution considerably more complex than has sometimes been suggested. ${ }^{14}$ Economically, use of a carried interest arrangement rather than salary does not actually convert ordinary income into capital gain but rather merely reallocates different types of income among partners, while leaving unchanged aggregate capital gain at the partnership level. To use a simple example, assume that a partnership has $\$ 100$ of capital gain and can choose to pay deductible salary of $\$ 20$ to an investment manager or, alternatively, reallocate $\$ 20$ of the partnership's capital gain to the investment manager. In this instance, the carried interest arrangement substitutes capital gain (the manager's share of partnership profits) for ordinary compensation income but deprives investor partners of an equal and offsetting compensation deduction (or capitalized expense).

In light of the furor over carried interests, it may be worth emphasizing that such income reallocation generally does not offer a jointtax advantage (or disadvantage) if all parties are taxed at the same rates on ordinary income and capital gain. ${ }^{15}$ The reallocation affects the amount of

11. See generally New York State Bar Association Tax Section, Report on Proposed Carried Interest Legislation and Fee Deferral Legislation (Sept. 28, 2008) [hereinafter NYSBA Report]; ABA Section of Taxation, Comments on H.R. 2834 (Nov. 13, 2007) [hereinafter ABA Comments].

12. See, e.g., Mark P. Gergen, A Pragmatic Case for Taxing an Equity Fund Manager's Profits Share As Compensation, 87 TAXES 139, 149 (2009) (noting that "[m]any of the problems that have been raised ... are technical in nature and solvable").

13. See Paul Carman, Taxation of Carried Interests, 87 TAXES 111, 134 (2009); see also Michael L. Schler, Taxing Partnership Profits Income As Compensation Income, 119 TAX Notes 829, 853 (2008) (describing the current approach as a "practical solution to a difficult problem").

14. See Sanchirico, supra note 5; David A. Weisbach, The Taxation of Carried Interests in Private Equity, 94 VA. L. REv. 715 (2008); see also Schler, supra note 13, at 853 (noting that "complexity will be inevitable").

15. To illustrate, assume that all parties are taxed on capital gains at $15 \%$ and on 
taxes paid, respectively, by the manager and investors (the manager pays less tax and the investors pay more tax) but total taxes remain unchanged. Because aggregate tax liability is the same, the parties may be expected to alter payments to each other so that their net income (after taxes) remains constant. ${ }^{16}$ If the investors are tax-exempt (or tax-indifferent), however, the carried interest arrangement decreases the service partner's tax without any offsetting increase in the other partners' tax. ${ }^{17}$ Notwithstanding the tax tensions among same-taxed partners that normally suffice to limit such taxadvantageous income reallocation, reformers have claimed that the private equity model revealed fundamental flaws in the taxation of partnership profits interests. ${ }^{18}$

ordinary income at $35 \%$. The two alternative compensation arrangements (carry versus cash) result in the same aggregate tax liability $(\$ 15)$; under the carried interest arrangement, the investment manager pays $\$ 4$ less tax (\$3 versus $\$ 7$ ) but taxable investors pay $\$ 4$ more $\operatorname{tax}(\$ 12$ versus $\$ 8)$ :

\begin{tabular}{|l|l|l|l|l|}
\hline & \multicolumn{2}{|l|}{ Taxable Income } & \multicolumn{2}{l|}{ Tax Liability } \\
\hline & $\begin{array}{l}\text { Carried } \\
\text { Interest }\end{array}$ & Salary & $\begin{array}{l}\text { Carried } \\
\text { Interest }\end{array}$ & Salary \\
\hline Investment manager & $20 \mathrm{CG}$ & $20 \mathrm{OI}$ & 3 & 7 \\
\hline Taxable investors & $80 \mathrm{CG}$ & $100 \mathrm{CG}-20 \mathrm{OI}$ & 12 & $15-7$ \\
\hline Total & $100 \mathrm{CG}$ & $100 \mathrm{CG}$ & 15 & 15 \\
\hline
\end{tabular}

16. Regardless of which party bears the nominal tax burden, a compensation arrangement is neutral as long as the parties' aggregate tax liability is the same. See, e.g., Ethan Yale \& Gregg D. Polsky, Reforming the Taxation of Deferred Compensation, 85 N.C. L. REV. 571, 580 (2007); Alan D. Viard, The Taxation of Carried Interests: Understanding the Issues, 61 NAT'L TAX J. 445, 450 (2008) (noting that "the parties can and should alter their payments to each other" to keep net income unchanged).

17. By comparison, use of carry (rather than cash) reduces the partners' aggregate tax liability by $\$ 4$ when the investor partners are tax-exempt:

\begin{tabular}{|l|l|l|}
\hline & Tax Liability \\
\hline & Carried Interest & Salary \\
\hline Investment manager & 3 & 7 \\
\hline Tax-exempt investors & 0 & 0 \\
\hline Total & 3 & 7 \\
\hline
\end{tabular}

The reduction in the partners' aggregate tax liability is equal to the 20 percentage point gap between the investment manager's rate on ordinary income $(35 \%)$ and rate on capital gains $(15 \%)$. The relevant rate gap for tax-exempt investors is zero, i.e., they bear no tax on capital gain or ordinary income; thus, the income reallocation saves joint taxes equal to the entire difference (\$4) between the investment manager's capital gain tax (\$3) and ordinary income tax (\$7). See Sanchirico, supra note 5, at 1114 (noting significance of difference in the partners' rate gaps).

18. See Fleischer, supra note 2 , at 4 (claiming that "the status quo is untenable as a matter of tax policy"). 
Although some commentators have argued that private equity carried interests might be used even if they offered no particular tax advantages, ${ }^{19}$ Part I of this Article suggests that these tax-motivated arrangements were clearly vulnerable under existing partnership rules that seek to limit capital-gain conversion and joint-tax minimization. Part II of the Article examines critically the compromise approach of $\S 710$, together with the partnership tax bar's recommended amendment of $\S 83$. Touted as a simple solution to conversion and deferral, the recharacterization approach of $\S 710$ may simply mask the inherent problems of distinguishing between labor and capital income when a service partner's earnings are reinvested in the partnership and give rise to "qualified capital." 20 Tracking the separate labor and capital components of a service partner's return when earnings are reinvested is part of a much larger problem when a business owner-manager invests both services and capital in an enterprise. This problem is exacerbated to the extent a service provider can receive a partnership profits interest tax free and be recognized as a partner even though his claim to a share of the partnership's capital is contingent on a performance goal. From the partnership tax bar's perspective, the current legislation offers a long-awaited opportunity to disentangle treatment of profits interests from $\S 83$, the general provision governing deferred compensation. ${ }^{21}$ Given the joint-tax incentives that $\S$ 710 provides to overstate investment return (and understate compensatory return), Part III concludes that a better approach may be to treat a service partner's profits share entirely as ordinary income even if implicit salary is reinvested in the partnership's business, by analogy to the treatment of restricted stock or nonqualified options.

While allaying the concerns of the partnership tax bar may be a practical imperative, it is abundantly clear that $\S 710$, if enacted, will be neither simple nor straightforward. Given the political salience and technical opacity of the carried interest problem, Congress might be well advised to delegate to Treasury authority under existing provisions to address capital-gain conversion rather than enact a complex statute of

19. See Weisbach, supra note 14 , at 726 (suggesting that "the structure of these funds is no more tax-driven than any typical investment").

20. See Prop. $\S 710(\mathrm{c})(2)(\mathrm{A})$ and (C) (exempting from ordinary income treatment reasonable allocations attributable to a service partner's qualified capital, including previously-taxed but undistributed earnings). The qualified capital exception under the Levin bill was expanded in response to recommendations of the partnership tax bar; it is not clear whether the Administration's budget proposal follows this approach.

21. See proposed $\S 83(\mathrm{a})(4)$ (treating the fair market value of a profits interest as equal to its liquidation value (zero) and deeming the recipient to have made a $\S 83$ (b) election). The revision to $\S 83$ was added to the Levin bill as a new "Section 1" that appears immediately before "Section 2" containing proposed $\S 710$. 
uncertain scope and effectiveness.

\section{PRIVATE EQUiTy FundS: AlLOCATIONS AND DISTRIBUTIONS}

If the tax advantage of private equity managers is properly viewed as a special form of joint-tax arbitrage, it is essential to understand how the partnership rules facilitate or limit such joint-tax minimization. A typical private equity fund is a self-liquidating partnership: both investors and the investment manager receive cash distributions at roughly the same time as the partnership recognizes gain from sale of investments and allocates that gain among partners. Because the manager typically does not reinvest capital earned from services in the partnership, taxing distributive shares may be equivalent to taxing distributions. If the fund is insufficiently profitable when it liquidates, the manager may be required to return only unearned after-tax distributions which represent essentially interest-free loans from the investor partners. ${ }^{22}$ Given the highly unusual nature of private equity arrangements that are structured to provide tax benefits to managers that are often intentionally opaque even to investors, it may be hazardous to draw any generalizations concerning how traditional partnership profits interests should be taxed.

\section{A. Understanding the Business Arrangements That Prompted Proposed $\$ 710$}

Although the structure and business model of private equity funds have attracted considerable public attention, the operation of the tax provisions is generally less well understood. ${ }^{23}$ The typical business arrangement is as follows. Assume the general partner (GP) of a private equity fund is an individual who provides management services, and the investors (LP) are tax-exempt entities (unless otherwise specified). ${ }^{24}$ The

22. See infra notes 57-61 and accompanying text.

23. This Article does not discuss hedge funds, which share some common characteristics with private equity funds but raise distinct tax issues. Since hedge funds typically generate mainly short-term capital gain (taxed at the same rate as ordinary income), they arguably do not pose the same problem. See Adam H. Rosenzweig, Not All Carried Interests Are Created Equal, 29 Nw. J. InT'L L. \& Bus. 713, 715 (2009).

24. In reality, the general partnership interest is likely to be held by a management company organized as a partnership or an LLC; the equity owners of the management company are private equity professionals. Since the management company is a flowthrough entity, the tax consequences are generally the same as if the private equity professionals held the general partnership interest directly. The investors are likely to be a composite of tax-exempt entities (e.g., private and governmental employee benefit plans and 
fund is organized as a partnership (P), although the result would generally be the same if $\mathrm{P}$ were instead an LLC taxed as a partnership. P seeks to acquire control of portfolio companies, increase the value of the portfolio companies, and "monetize" the return on LP's investment over a period of several years. ${ }^{25}$ GP receives solely a profits interest in exchange for services; since GP contributes no capital to P, there is no need to bifurcate GP's interest between a capital and a profits component. ${ }^{26}$ Over time, GP will acquire a capital interest in P to the extent of GP's share of any previously taxed but undistributed profits; if all profits are distributed currently, GP never acquires a capital interest. Prior to liquidation, GP shares in distributions to the extent that current realized gains exceed the aggregate excess of losses over gains on investments sold in prior years. ${ }^{27}$ $P$ imposes a clawback obligation on GP to the extent that GP has a negative capital account on liquidation attributable to "unearned" distributions. ${ }^{28}$ The following example illustrates the typical business arrangement and the close economic resemblance between a profits interest and an option.

Example (1)-Earned Carry. In exchange for managing P's business, GP receives a $20 \%$ profits interest; LP contributes $\$ 40$ million and is entitled to the remaining $80 \%$ of P's profits. LP is not entitled to a preferred return or minimum return on investment ("hurdle rate"). In Year 1, P makes four portfolio investments (A, B, C, and D) of $\$ 10$ million each. At the end of Year 2, P sells A for \$15 million; at the end of Year 3, P sells

university endowments), foreign individuals, and wealthy U.S. individuals. This Article ignores the possibility that some portion of U.S. tax-exempt investors' return may be unrelated business taxable income (UBTI). See I.R.C. § 512 (2009).

25. See Fleischer, supra note 2, at 8-9. Since LP is "locked into" P until disposition of all the portfolio companies, LP's capital is returned only as $\mathrm{P}$ distributes proceeds from the sale of individual portfolio companies. See Knoll, supra note 6, at 122-23.

26. To ensure partner status, GP would typically contribute capital (1\%); GP would also be entitled to a management fee (2\%). If the rights of GP's capital interest are identical to those of LP's, the price paid by LP provides a proxy for the fair market value of GP's capital interest. Cf. Carman, supra note 13, at 124-25 (comparing non-U.S. solutions to the carried interest problem, including allowing non-service partners to invest in carried interest units).

27. See Andrew W. Needham \& Anita Beth Adams, Private Equity Funds, 735 B.N.A. Tax Mgmt. Portfolio A-8 to A-9 (2005) (describing "realized aggregation" method). Other approaches to the timing of distributions may be more or less favorable to GP. See Jack S. Levin, Structuring Venture Capital, Private Equity, and Entrepreneurial TRANSACTIONS $\uparrow 1003$ (2008).

28. The clawback obligation is a contingent recourse obligation to repay all or a portion of distributions received prior to liquidation so that GP's cumulative distributions coincide with the profit-sharing formula. See James M. Schell, Private Equity Funds: Business Structure AND OPERATIONS 1-9 (1999). If GP is organized as a limited liability entity, LP may insist on guarantees to ensure that the contractual obligation is satisfied. See id. at 2-26. 
$\mathrm{B}$ for $\$ 8$ million; and at the end of Year $4, \mathrm{P}$ sells $\mathrm{C}$ for $\$ 12$ million. Finally, at the beginning of Year 5, P sells D for $\$ 10$ million and liquidates.

At the end of Year 2, P realizes gain of $\$ 5$ million on sale of A ( $\$ 15$ million less $\$ 10$ million basis). To recoup LP's investment in A, P distributes the first $\$ 10$ million of sales proceeds to LP; the remaining $\$ 5$ million is distributed \$4 million to LP and \$1 million to GP (in the same manner as the realized gain of $\$ 5$ million is allocated). Even though GP receives a distribution of $\$ 1$ million at the end of Year 2, GP's carry is not "earned" until LP's aggregate invested capital is fully returned. ${ }^{29}$ Prior to liquidation, the partnership recognizes net gain of $\$ 5$ million ( $\$ 5$ million gain on A less $\$ 2$ million loss on B plus $\$ 2$ million gain on $\mathrm{C}$ and zero gain on D). Overall, GP receives $\$ 1$ million (the earned carry) and LP receives $\$ 44$ million ( $\$ 40$ million plus $80 \%$ of the $\$ 5$ million net gain).

In economic terms, GP's profits interest is indistinguishable from an option, i.e., the ability to benefit from an increase in appreciation without risking capital. $^{30}$ If GP had an option on $20 \%$ of the net increase in the value of $\mathrm{P}$ ( $\$ 5$ million), GP would recognize $\$ 1$ million of ordinary income upon exercise of the option; the tax would be deferred from grant until exercise of the option; all of the partnership's capital gain would be taxed to $\mathrm{LP}$, and $\mathrm{P}$ would be treated as paying over compensation of $\$ 1$ million to GP on exercise of the option, with a corresponding deduction (or capitalized expense). ${ }^{31}$ Under the profits alternative, GP's carry of $\$ 1$ million is instead taxed entirely as long-term capital gain, saving GP the difference between the capital gain rate and the ordinary income rate. By comparison to an economically equivalent option, profits treatment accelerates taxation of GP, since GP is taxed when partnership income is allocated to him (whether or not distributed). Despite acceleration of the tax, profits treatment produces a more favorable tax result overall because it allows GP to convert ordinary income into capital gain. Moreover, profits treatment permits GP to extract early cash distributions tax free that may nevertheless need to be repaid later.

Despite the economic resemblance of a profits interest to an option, the Internal Revenue Service ("Service") will generally respect the partner status of a service provider who receives a profits interest falling within the

29. See SCHELL, supra note 28 , at 2-21 (noting that the profitability of the investment cannot "be known with certainty until [P] is liquidated and wound up").

30. See Knoll, supra note 6, at 133 (noting that "a carried interest is effectively a call option."). A profits interest closely mimics a nonqualified stock option (NQSO) or incentive stock option (ISO). See Fleischer, supra note 2, at 4.

31. Upon exercise of the option, the holder acquires a capital interest; grant of the option is not a taxable event. See Treas. Reg. $\S \S 1.83-7$ (a) (as amended in 2004), 1.83-6(a) (as amended in 2003). 
administrative guidelines of Revenue Procedures 93-27 and 2001-43. ${ }^{32}$ A private equity carried interest does not, however, fall within the literal terms of the administrative safe harbor, since the holder typically receives both a capital interest and a disproportionate profits interest. ${ }^{33}$ Nevertheless, taxpayers may claim that the carried interest can be bifurcated into separate capital and profits components for purposes of qualifying the profits interest under the safe harbor. ${ }^{34}$ Alternatively, taxpayers may simply claim a zero value based on the confused state of current law, relying on the government's perceived unwillingness to challenge even patently erroneous valuations. $^{35}$ If receipt of the profits interest is not taxed up front, GP is taxed on his distributive share of partnership profits under the normal flowthrough rules of $\S 702(\mathrm{~b}){ }^{36}$

When LP is tax exempt (or otherwise tax indifferent), GP essentially "swaps" ordinary income for capital gain at no tax cost to LP, since a deduction for GP's implicit salary would be worthless to LP. ${ }^{37}$

32. See Rev. Proc. 93-27, 1993-2 C.B. 343; Rev. Proc. 2001-43, 2001-2 C.B. 191. In 2005, the Service issued proposed regulations addressing compensatory transfers of partnership interests. See Proposed Regulations on Partnership Equity Transfers for Services, REG-105-346-03, 70 Fed. Reg. 29,675 (May 24, 2005) [hereinafter REG-105-34603]; Notice 2005-43, 2005-1 C.B. 122 (containing proposed revenue procedure). The 2005 proposed regulations were generally consistent with the Service's prior administrative guidance, which would have become obsolete had the proposed regulations become final.

33. See Carman, supra note 13, at 114 (noting that a carried interest does not "literally fall within" the safe harbor); $c f$. Fleischer, supra note 2, at 12 ("The typical carried interest finds ample shelter in the proposed rules.”). By allowing a liquidation-value election for all compensatory partnership interests (capital or profits), the 2005 proposed regulations would have extended safe harbor treatment to certain carried interest arrangements not covered by the prior administrative rule.

34. While it might seem "illogical" to construe the Service's administrative guidance narrowly not to permit bifurcation, adopting "the rational, taxpayer-friendly, more expansive reading" would represent a significant change in the status quo. LEVIN, supra note 27 , व 1006 at $10-19$.

35. See Campbell v. Comm'r, 943 F.2d 815 (8th Cir. 1991) (holding value of profits interest was too speculative). In 2001, the Service adopted a surprisingly pro-taxpayer position by extending the favorable liquidation-value rule even if a profits interest is substantially nonvested at grant and no $\S$ 83(b) election is made. See Rev. Proc. 2001-43, 2001-2 C.B. 191 (deemed $\S 83$ (b) election).

36. Under $\S 83$ principles, the service partner could be taxed on the fair market value of the profits interest upon receipt. Because of valuation difficulties, however, the front-end approach of taxing GP upon receipt of the interest is not a realistic alternative. See H.R. REP. No. 110-728 at 17 (2008) (§ 710 "takes a different approach"). Under current law, GP has no back-end ordinary income upon vesting of the interest, assuming a taxpayer-favorable resolution of the liquidation-value issue under the Service's administrative guidance. See LEVIN, supra note 27, 1006 at 10-20.

37. See Sanchirico, supra note 5, at 1078, 1115-16 ("The true tax advantage [of a carried interest] over other arrangements is the ability to swap tax character with partners who are differently taxed."). Unless GP is taxed differently from LP, there is no tax 
Jointly, LP and GP improve their economic situation solely at the expense of the government. Since a profits interest does not actually convert capital gain into ordinary income but rather merely reallocates capital gain among the partners, the arrangement may appear technically to be outside the elaborate $\S 704$ (b) regulations governing when partnership allocations will be respected. This type of joint-tax arbitrage would, however, clearly violate the $\S 704(\mathrm{~b})$ regulations if it involved an actual swap of equal amounts of ordinary income and capital gain. ${ }^{38}$ The $\S 704(\mathrm{~b})$ tax-avoidance test is merely a subset of the general $\S 701$ anti-abuse rule, which permits the Service to treat a partnership as an aggregate (rather than an entity) to properly reflect income. ${ }^{39}$ Indeed, $\S 707(\mathrm{a})(2)(\mathrm{A})$ addresses the problem of compensatory allocations and distributions intended to circumvent other limitations -including the capitalization requirement and conversion of ordinary income into lower-taxed income. ${ }^{40}$

Despite this array of anti-abuse rules aimed at joint-tax arbitrage, the carried interest debate has been popularly framed mainly in terms of the one-sided advantage to GP who defers tax and converts ordinary income into capital gain. ${ }^{41}$ Other commentators have perceived that the tax advantage of profits interests involves essentially reallocation of capital gain among taxable and tax-exempt (or tax-indifferent) partners, but have nevertheless failed to recognize that such joint-tax minimization offends

advantage to the carried interest. See id. at 1114 (noting that it is "not a difference in tax rates per se, but a 'difference in differences"' that matters).

38. See Treas. Reg. $\S \S 1.704-1(b)(2)(i i i)(a)$ (overall tax-effect rule), 1.7041(b)(2)(iii)(b) (as amended in 2008) (character allocations that shift tax consequences); see also I.R.C. § 751 (2009) (prohibiting shifting of ordinary income and capital gains). Because the swap is merely a putative swap - the prohibited shifting of tax consequences is embedded in the structure of the transaction rather than P's formal allocation provisionsthe assumption is that $\S 704(\mathrm{~b})$ is not violated.

39. See Treas. Reg. § 1.701-2 (1995); Senate Hearings, supra note 1, at 2 n.4 (Statement of Charles I. Kingson, July 31, 2007) ("If the partnership anti-abuse rule has any bite, use of a partnership to claim capital gain from performing services should have been high on the list. But conflicts apparently prevented even bar associations from raising this.").

40. I.R.C. $\S 707(a)(2)(A)$ may be understood narrowly to avoid reaching private equity managers' compensation. See Weisbach, supra note 14, at 731-32 (explaining that $\S$ 707(a)(2)(A) applies only to distributions not subject to substantial entrepreneurial risk); see also Gergen, supra note 3, at 77 ("The line $[\S 707(\mathrm{a})(2)(\mathrm{A})]$ draws relates poorly to the real policy concern, and the line is poorly drawn."). C $f$. American Law Institute, FEDERAL Income Tax Project: Subchapter K, Proposals on the Taxation of Partners 155-64 (1984).

41. See Sanchirico, supra note 5, at 1077 n.14 (noting that the joint-tax perspective "is oddly neglected in the treatment of private equity profits interests"); Knoll, supra note 6, at 126-27 (noting that "the tax consequences . . . should be evaluated globally, for all parties to a transaction, not just for one party in isolation."). 
fundamental principles of partnership taxation. ${ }^{42}$ Because the reform debate largely overlooked existing partnership anti-abuse rules, Congress may have failed to fully appreciate alternative solutions.

\section{B. Economic Risk of Loss and Deemed Taxes}

In the carried interest debate, the fundamental issue is whether GP should be respected as a partner even though his interest is in all respects essentially identical to that of an option holder. As a putative profits holder, GP has a right to share in future appreciation if $\mathrm{P}$ increases in value above $\$ 40$ million but bears no risk of loss except for the contingent obligation to restore "excess" distributions. ${ }^{43}$ If $\mathrm{P}$ initially realizes investment gains and subsequently incurs investment losses, the early distributions to GP may exceed $20 \%$ of P's aggregate gains over P's life cycle, triggering the clawback provision. The function of the clawback provision is to align the parties' respective economic interests, particularly given GP's control over the timing of gain recognition, and to achieve cumulative aggregation of gains.

Example (2)-Unearned Carry. The facts are the same as in Example (1), except that $\mathrm{P}$ sells $\mathrm{D}$ for only $\$ 5$ million, triggering a $\$ 5$ million loss ( $\$ 5$ million less $\$ 10$ million basis). Overall, $\mathrm{P}$ just breaks even (ignoring the time value of money); since $\mathrm{P}$ has no cumulative profits, GP's entire $\$ 1$ million of distributions should apparently be clawed back. ${ }^{44}$ In reality, GP's clawback is often limited to after-tax distributions. Typically, GP takes the position that the clawback obligation should be reduced by reference to a hypothetical tax rate, often determined by reference to the highest tax rate applicable to the income earned. Assume that $\mathrm{P}$ employs a "net-of-tax" formula that reduces the clawback by reference to an assumed marginal rate of $25 \%{ }^{45}$ In this event, GP must return the lesser of (1)

42. Indeed, one commentator concluded just the opposite: namely, that the partnership rules give carte blanche to partners to reallocate income to minimize taxes and to avoid other restrictions. See Viard, supra note 16, at 459 ("The reallocation is an application of economy-wide partnership tax rules.").

43. More precisely, losses are allocated in the same manner as prior allocations of profits until such losses have offset all previously allocated profits; any additional losses are allocated $100 \%$ to contributed capital.

44. If GP restored $\$ 1$ million to $\mathrm{P}, \mathrm{LP}$ would receive $\$ 6$ million on liquidation ( $\$ 5$ million from sale of D and \$1 million from GP's contribution). Cumulatively, LP would receive $\$ 40$ million and GP would receive zero.

45. See Needham \& Adams, supra note 27, at A-10 to A-11; Paul H. Asofsky \& Andrew W. Needham, U.S. Private Equity Funds: Common Tax Issues For Investors and Other Participants, 630 PLI/TAX 1275, 1308 (2004) ("Most fund clawback provisions net the maximum clawback against taxes attributable to the carried interest allocations. How 
excess carry distributions ( $\$ 1$ million) or (2) the aggregate after-tax distributions received by GP ( $\$ 1$ million less $0.25 \times$ x $\$ 1$ million). In GP's view, it would be unfair to require return of more than $\$ 0.75$ million, since GP should not be required to give up more than he actually retained after tax. ${ }^{46}$ In effect, LP pays GP's hypothetical taxes by foregoing full return of LP's committed capital. If the hypothetical tax rate exceeds GP's effective marginal tax rate, the net result is that GP earns a positive return even though LP's return is negative.

On sale of D, GP is allocated loss up to the amount of the clawback obligation ( $\$ 0.75$ million); on liquidation, GP repays the unearned carry (net of taxes) by restoring the $\$ 0.75$ million deficit in his capital account (rather than the full $\$ 1$ million distribution). To create the proper deficit balance for GP, P simply "backs into" the desired amount. ${ }^{47}$ Under a target-allocation approach, the partnership's allocations are determined after gains and losses are realized, taking into account the partnership's distribution "waterfall." Technically, target or "forced" allocations do not comply with the capital account requirements of the $\S 704$ (b) regulations, since distributions govern capital accounts (rather than the reverse) ${ }^{48}$ While target allocations flunk the $\S$ 704(b) safe harbor rules, they may (or may not) satisfy the alternate "partner's interest" test. ${ }^{49}$ If $\mathrm{P}$ disregards capital account balances on liquidation, however, the validity of the prior allocations should be subject to challenge.

If GP's clawback obligation is reduced by deemed taxes paid, it might appear that it should also be increased by reference to any offsetting tax benefits received by GP. Typically, however, the clawback provision ignores the tax benefit to GP from the capital loss generated by the clawback itself. ${ }^{50}$ Since GP derives a tax benefit only if GP has unrelated

funds compute this offset, however, varies widely in the industry."). The hypothetical tax rate is intended to achieve "rough justice" among all of the partners, without looking to any partner's particular tax circumstances. For example, if GP has unrelated losses that offset GP's income from P, GP's effective tax rate will be lower than the deemed tax rate.

46. In this event, LP recovers only $\$ 39.75$ million (rather than $\$ 40$ million). The missing $\$ 0.25$ million is the amount of taxes (at the hypothetical tax rate) paid on the $\$ 1$ million of net gain allocated to GP (prior to sale of D).

47. Under a target allocation approach, items of income and loss are allocated in a manner that should cause GP's capital account to equal the amount that GP would receive (or be required to contribute) on liquidation. See Needham \& Adams, supra note 27, at A16 (noting that target allocation "plugs" the required change in capital account balances over the relevant period).

48. See Treas. Reg. $\S 1.704-1(b)(2)(i i)(b)$ (as amended in 2008). The regulations warn that invalid allocations may give rise to appropriate tax consequences under $\S \S 61$ and 83 . See Treas. Reg. § 1.704-1(b)(1)(iv) (as amended in 2008).

49. See Treas. Reg. § 1.704-1(b)(1)(i) (as amended in 2008).

50. See Needham \& Adams, supra note 27, at A-10. While the potential tax 
capital gains to offset the capital loss on liquidation, the clawback provision arbitrarily treats GP's tax benefit as zero. If GP can fully utilize the capital loss, GP receives a windfall at the expense of LP. Because measuring GP's actual tax benefit is administratively difficult or because GP has superior bargaining power, LP may be willing to accept the risk of such a windfall. ${ }^{51}$

To summarize, LP bears the entire economic risk of loss if $\mathrm{P}$ fails to earn a positive return on LP's invested capital over the life of the partnership. Even though GP initially receives a distribution of $\$ 1$ million in Year 2, GP is obligated in Example (2) to return only the net after-tax distribution (without interest) in Year 5. Under the terms of the partners' arrangement, the actual burden of the taxes paid on GP's share of partnership gain falls on LP, not GP. Consistent with the underlying economics, LP furnishes the partnership's entire capital and effectively bears the tax burden attributable to gain allocated to GP to the extent that GP fails to earn carry. There is a strong argument that GP should not be respected as a partner if, in a worst-case scenario, LP effectively bears the burden of taxes nominally imposed on GP and the underlying arrangement is intended merely to reduce the parties' joint-tax liability. ${ }^{52}$ Allocating $\$ 1$ million of gain to GP in Year 2 allows GP to swap ordinary compensation income for capital gain, even though repayment of the net after-tax distribution leaves GP no worse off than if the entire gain were allocated to LP.

\section{C. $\quad$ Timing of Distributions and Disguised Loans}

The partnership's allocation provisions determine how gain or loss is shared among the partners when realized by the partnership. By contrast, the distribution provisions determine when partners will actually receive cash from the partnership. If income has previously been taxed to a partner, the corresponding distributions are generally tax free. ${ }^{53}$ Depending on the

consequences vary, the funding of the clawback obligation will generally result in a shortterm capital loss to GP; non-corporate taxpayers are not permitted to carry back capital losses in order to offset capital gains in prior years. See I.R.C. $\S \S 1211(b), 172(d)$ (2009).

51. See Needham \& Adams, supra note 27, at A-10. To mitigate the likelihood of a clawback arising, P may choose to "write down" any unrealized losses in assets not yet sold and treat such losses as if actually incurred.

52. If LP bears the burden of the taxes nominally imposed on GP's allocable share of profits, GP's willingness to be taxed on such implicit salary is not economically meaningful. While the assumption that no carry is earned may seem counterintuitive if investors expect assets to be sold for an amount in excess of their carrying cost, the $\S 704$ (b) capital-account analysis nevertheless tests the validity of allocations based on a hypothetical worst case. See Treas. Reg. § 1.704-1(b)(2)(ii) (as amended in 2008).

53. See I.R.C. $§ 731$ (2009). 
substance of the parties' economic arrangement, however, a purported distribution may represent a disguised payment for services or an implicit loan and be taxed accordingly. ${ }^{54}$

From GP's perspective, the timing of distributions is apparently paramount. GP is likely to resist strenuously the notion of deferring distributions until all of P's assets are sold and P is wound up. Since the clawback obligation is unsecured, however, LP risks that GP will lack sufficient funds to restore excess carried interest distributions. This credit risk could be solved by requiring escrow of all or a portion of GP's distributions until LP has received a return of all prior contributions. ${ }^{55}$ Nevertheless, private equity funds rarely follow this approach, perhaps based on the implicit assumption that "unrealized investments will generate proceeds at least equal to their carrying value." ${ }^{, 56}$ Like the provision concerning deemed taxes paid, the distribution methodology is a function of the parties' relative bargaining power. As an economic matter, GP's preference for early distributions may nevertheless be somewhat puzzling. In theory, the timing of distributions should be irrelevant, since adjustments to the terms of the parties' arrangement are possible to reflect the present value of accelerated or deferred distributions. ${ }^{57}$ Indeed, GP should be able to borrow against his share of undistributed profits to replicate the cashflow consequences of accelerated distributions. ${ }^{58}$

While often overlooked in the carried interest debate, the choice of distribution rules may significantly enhance GP's overall compensation. GP effectively borrows at no interest from LP in exchange for a contingent recourse liability to repay unearned distributions upon liquidation. The $\S$ 704(b) capital account rules do not identify implicit loans among partners or require interest to be charged on deficit restoration obligations; nor does GP's interest-free borrowing fall within the rules of $\S 7872$ for belowinterest loans. ${ }^{59}$ The valuable no-interest loan embedded in the opaque and manipulable distribution rules may help to reinforce GP's preference for

54. See, e.g., I.R.C. § 707 (2009).

55. SCHELL, supra note 28, at 2-27 (noting that the escrow approach "is strongly resisted"); see also Kate Litvak, Venture Capital Limited Partnership Agreements: Understanding Compensation Arrangements, 76 U. CHI. L. REV. 161, 177 (2009) (describing the escrow approach as least favorable from GP's perspective, since GP "has, in effect, made an interest-free loan to investors"). Of course, GP could be credited with interest on the escrowed amounts. See Asofsky \& Needham, supra note 45, at 1310.

56. SCHELL, supra note 28 , at 2-21.

57. See Litvak, supra note 55, at 176.

58. Cf. id. (noting sponsors' claim that "borrowing from outside lenders against future income [would be] prohibitively expensive").

59. See Treas. Reg. $\S 1.704-1(b)(2)(i i)(c)$ (as amended in 2008). Cf. I.R.C. $\S 7872$ (2009) (governing interest-free loans generally between employees and employers). 
early distributions. ${ }^{60}$ By using a profits interest (rather than an economically equivalent option), GP gains access to implicit interest-free loans as well as the opportunity to convert ordinary income into capital gain; thus, the tax advantage alone may be only a partial explanation of GP's desire for a carried interest arrangement. Since drafting the intricate distribution provisions is preeminently the task of tax lawyers, even sophisticated parties may not fully comprehend the economic import of these ordering rules. ${ }^{61}$

If $\mathrm{P}$ held back carried interest distributions, it would nevertheless provide for tax distributions to GP sufficient to pay GP's deemed taxes on allocated income. To eliminate the possibility that a service partner will incur tax liability in excess of distributions for a particular period, the nearly universal practice is to require priority tax distributions to address timing problems. $^{62}$ The business justification for mandatory tax distributions is that taxes on the firm's entire income must be paid before determining any economic profit. ${ }^{63}$ If the enterprise were operated in corporate form, the tax would be incurred at the corporate level, effectively burdening the return to the preferred interest. Similarly, LP should be entitled to its preference (return of capital and any hurdle rate) only after setting aside cash sufficient to pay taxes on the firm's income. Given the parties' interest in maximizing joint after-tax returns, the nominal tax burden should be allocated in whatever manner minimizes the partners' joint-tax liability. ${ }^{64}$

Under existing $\S 707(a)(2)(A)$, Congress delegated authority to Treasury to distinguish disguised payments from true distributive shares. ${ }^{65}$ Under that provision, a purported allocation and distribution may be recharacterized as a nonpartner payment. If GP were treated as a nonpartner, P's entire income would be reallocated to LP and LP would be deemed to transfer $\$ 1$ million to GP in Year 2 as compensation or a

60. See Litvak, supra note 55 , at 163 ("[T]he interest-free loan is both opaque and highly valuable.").

61. See id. at 196 (referring to distribution rules as possible evidence of "contractual complexity ... used to increase stealth compensation").

62. See SchELL, supra note 28, at 2-23 (noting that "acceptance of this minimal distribution is all but universal").

63. While the partnership model eliminates an entity-level tax, mandatory tax distributions mimic the result under the corporate model. See Robert P. Rothman, Translating Corporate Concepts into the Language of LLCs, 61 TAX LAW. 161, 174-76 (2007). The tax distribution provision is less important if GP receives current distributions, but it nevertheless affects the clawback calculation.

64. See Sanchirico, supra note 5, at 1143 (noting that the nominal incidence does not affect "real tax burdens, given the adjustability of wages and salaries").

65. For the origins of $\S 707(\mathrm{a})(2)(\mathrm{A})$, see Karen C. Burke, Back to the Future: Revisiting the ALI's Carried Interest Proposals, 124 TAX Notes 242, 243-44 (2009). 
disguised interest-free loan. In Example (1), if the purported distribution were treated as a loan (leaving aside possible imputed interest under $\S$ 7872), GP would be taxed on ordinary income of $\$ 1$ million upon liquidation of $\mathrm{P}$, since GP's obligation to repay the loan is eliminated; the result would be the same as if GP were treated as holding an option exercisable immediately prior to liquidation of $\mathrm{P}^{66}$ Nonpartner treatment under $\S 707(a)(2)(A)$ would thus eliminate GP's ability to convert salary into capital gain but would potentially permit longer deferral, by analogy to an option exercised upon liquidation of the partnership.

\section{Earned Capital}

In the baseline case of a self-liquidating private equity partnership, taxing distributions and taxing distributive shares may seem to be a distinction without a difference. Thus, it is perhaps easy to understand how the recharacterization approach - treating a profits allocation as ordinary income-popularly came to be confused with taxing distributions, not distributive shares. If earnings are never accumulated for later distribution, the service partner does not acquire any "earned capital." In the context of a private equity fund, the problem of earned capital - income taxed to a service partner as ordinary income and reinvested in the enterprise - simply does not arise because all profits are distributed currently. Since many partnerships routinely reinvest earnings, however, complex adjustments are necessary when distributions are deferred. ${ }^{67}$ If earnings from services are reinvested in the enterprise, some mechanism is needed to track separately the labor and capital components of a service partner's future return. Indeed, the partnership tax bar has seized the opportunity to "improve" reform by meticulously working out the logical consequences of an earned capital exception, injecting further complexity and electivity.

The notion of earned capital, however, assumes that a service partner who has a forfeitable interest should nevertheless be recognized as a partner. Treating such a service provider as a partner is contrary to the

66. In Example (2), reallocating partnership income entirely to LP would eliminate the $\$ 0.25$ million of tax, since the investment return would be taxed at LP's zero rate; if LP loaned the full \$1 million interest-free to GP, GP would repay the entire amount (rather than only $\$ 0.75$ million) on liquidation.

67. See NYSBA Report, supra note 11, at 28 (noting that, unlike private equity funds, "other funds, in particular hedge funds and many real estate funds, routinely reinvest previously-taxed earnings in new portfolio investments." In response to the bar's comments, the current proposal carves out an exception for investment returns to earned capital; simply put, such investment returns are subtracted from GP's profits share and taxed as capital gain. See infra notes 132-154 and accompanying text. 
normal rules of $\S 83$, the general provision governing receipt of property in connection with services. ${ }^{68}$ In light of the potential conflict between $\S 83$ and the partnership rules, the partnership tax bar has long sought a special rule that would exempt a profits holder whose interest is forfeitable from the normal operation of $\S 83$. From the partnership tax bar's perspective, the ordinary income approach favored by reformers is nothing new. Historically, the ordinary income approach harkens back to proposals by William McKee and others in the 1970's as a compromise solution to the potential conflict between $\S 83$ and the partnership rules. ${ }^{69}$

While reformers perhaps unwittingly borrowed the ordinary income approach as a solution to the carried interest problem, the McKee proposal antedated the modern capital account system. The complex capital account system makes it possible, in theory, to track the separate labor and capital components of a service partner's interest when earnings from services are reinvested in the partnership. Indeed, it may be possible to refine the McKee proposal to take into account previously taxed and reinvested salary as a source of future capital gains, by "disaggregating" a service partner's return into separate labor and capital components. Yet capital accounts may be a shaky foundation for reform, and the earned capital exception may be a misnomer. When GP has solely a profits interest contingent on a performance goal, the fundamental issue is whether GP or LP should be treated as owning partnership capital that generates an investment return taxed as capital gain. ${ }^{70}$ If, upon closer inspection, $\S 710$ is not the simple solution touted by reformers, a better approach may be to deny partner status to a service provider who is essentially in the same position as an option holder.

68. Section 83 requires a person who receives property in connection with performance of services to include the value of such property in income when such property first becomes "transferable" or is no longer subject to a "substantial risk of forfeiture." See I.R.C. $\S$ 83(a)(1) (2009). In the absence of a $\S 83(\mathrm{~b})$ election, the taxable event occurs when the transferred property becomes substantially vested. See Treas. Reg. $\S 1.83-3$ (b) (as amended in 2005). Prior to vesting, the transferor (not the transferee) is treated as the owner of such property. See Treas. Reg. $§ 1.83-1($ a)(1) (as amended in 2003).

69. See infra notes 108-111 and accompanying text.

70. See Senate Hearings, supra note 1 (Statement of Charles I. Kingson, July 31, 2007) ("The debate over carried interests should be seen as part of a derivative free-for-all, a sort of financial check-the-box regime, in which people can choose between the tax attributes of owning or not owning property."). Kingson was apparently the only witness who suggested that an investment manager's return should already be taxed as ordinary income under current law. Id. See also Charles I. Kingson, Carried Interests: An Outdated Term?, 123 TAX Notes 627 (2009) ("A bill to tax hedge fund managers on their share of the profits as ordinary income probably loses revenue ... [A] statute ratifies their previous position.") [hereinafter Kingson, Carried Interests: An Outdated Term?]. 


\section{PROPOSED $\S \S 710$ AND 83}

Although hardly novel, the recharacterization approach of $\S 710$ follows broadly the proposal of reformers who argued that a service partner's distributive share should be treated as ordinary income from compensation. Rather than address joint-tax minimization by reallocating income between service providers and investors, the recharacterization approach affects the treatment of only one party to the transaction. Such an approach is theoretically flawed but arguably represents an appealing political compromise: it preserves the status of a service provider as a partner, suspends the taxable event until profits are allocated to the service provider, and treats investor partners no less favorably than under current law. ${ }^{71}$ Consistent with the "technical" recommendations of the partnership tax bar, the Levin bill amends $\S 83$ to provide a statutory exception for profits interests (the zero-value approach), offering an unwarranted valuation subsidy for valuable profits interests. Section 710 would be both complex and easily avoidable: tax-exempt investors and service providers would have a joint-tax incentive to opt out of $\S 710$ by restructuring a profits interest as an economically equivalent option to achieve yield exemption and longer deferral.

\section{A. Ordinary Income Treatment}

In the reductionist version of the story told to Congress, the undertaxation of GP-who earns compensation for services but is taxed at the capital gains rate - creates a fundamental problem of distributive justice. $^{72}$ Such undertaxation is attributable to a "quirk" of partnership tax law that treats receipt of a profits interest as nontaxable, thereby allowing deferral and conversion. ${ }^{73}$ Rather than challenge the partner status of a service provider who holds an option-like interest, reformers focused narrowly on the characterization rule of $\S 702(b)$. Under that rule, the character of income in the hands of the partnership determines the character

71. See NYSBA Report, supra note 11, at 14.

72. See House Hearing, supra note 1 (Statement of Victor Fleischer, Sept. 6, 2007, at 4) (to some, "the most compelling point is simply one of distributive justice."). While the proposed legislation might offer fresh opportunities for gamesmanship, such challenges were viewed as surmountable. Id. at 7 ("[T] hese details can be ironed out, and we should not let the private equity industry's threat of further gamesmanship justify inequities and inefficiencies in the current law.").

73. Fleischer, supra note 2, at 5 (describing the "quirk in the partnership tax rules [that] allows some of the richest workers in the country to pay tax on their labor income at a low effective rate"). 
of the income in the hands of the partner. Indeed, such "conduit" treatment has long been perceived to be at the heart of the partnership tax rules. ${ }^{74}$ Faulting the conduit rule as the source of capital-gain conversion, reformers proposed a simple solution to redress a serious inequity: recharacterize income passed through to GP as ordinary income. ${ }^{75}$ Consistent with this solution, § 710 overrides the long-standing character flow-through rule under $\S 702$ and treats disproportionate allocations to GP as ordinary income (or loss). ${ }^{76}$ Simply stated, the net effect is to increase the tax rate on GP's implicit salary from $15 \%$ to $35 \%$, without altering the tax consequences to LP. ${ }^{77}$ The tradeoff for increasing the tax rate on GP is preserving intact the existing favorable treatment of LP. ${ }^{78}$

Proposed $\S 710$ exempts from ordinary income treatment an allocation that reflects a reasonable return on a service partner's "qualified capital interest." ${ }^{, 79}$ Qualified capital consists initially of the amount of money, the fair market value of any property contributed to the partnership, and the amount (if any) taxed to the service partner upon receipt of a profits interest. ${ }^{80}$ Upward (or downward) adjustments must be made to a service partner's share of qualified capital to reflect net income (or net loss) as well

74. See George K. Yin \& Karen C. Burke, Partnership Taxation 47 (2009) (noting that courts refer to $\S 702$ (b) as the "conduit rule").

75. See Fleischer, supra note 2, at 51 (referring to "Ordinary-Income Method"); Senate Hearings, supra note 1 (Statement of Mark P. Gergen, July 11, 2007) ("There is a fairly simple solution to the problem of the taxation of carried interests .... The capital accounts system . . . makes this fairly easy to do."); $i d$. ("The capital account makes it possible to identify when a distributive share is compensation.").

76. Compare I.R.C. $§ 702$ (b) (2009) (character of any item included in partner's distributive share "shall be treated as if such item were realized directly from the source from which realized by the partnership") with Prop. $§ 710(a)(1)$ ("Notwithstanding section 702(b)," any net income or loss "shall be treated as ordinary income [or] ordinary loss.").

77. Assuming that most LPs are tax exempt, the one-sided change in the tax treatment of GP would result in a net increase in revenue. See Knoll, supra note 6, at 129 (noting that untaxed investors provide at least $50 \%$ of private equity capital). Carried interest allocations recharacterized as ordinary income would also be subject to Social Security and Medicare taxes as self-employment income. See Prop. § 710(a)(1)(A); I.R.C. § 1402 (2009).

78. See Schler, supra note 13 , at 839 (noting that Prop. $\$ 710$ approach "is theoretically incorrect, but on balance it is a reasonable and generally pro-taxpayer result").

79. See Prop. $\S 710(c)(2)(A)(i)-(i i)$ (allocations must be made "in the same manner" as allocations made to non-service partners that are "significant" in comparison to allocations made to service partners); Prop. $§ 710(\mathrm{c})(2)(\mathrm{C})$ (defining a qualified capital interest). See also NYSBA Report, supra note 11, at 20-24 (describing the "reasonable allocation" requirement under prior versions of the carried interest legislation).

80. See Prop. $\S 710(c)(2)(C)(2009)$. A service partner's qualified capital will initially be zero (the liquidation value of the profits interest), unless the partner owns a separate capital interest. See Prop. $\S 710(c)(2)(C)(i i)$ (treating as qualified capital the amount of income included under proposed $\S 83$ upon grant). 
as distributions of cash and property. ${ }^{81}$ If all earnings are distributed currently, GP never acquires qualified capital from retained earnings ("earned capital"), and $\S 710$ has the same net result as taxing all distributions to GP as ordinary income. In all other situations, the operation of $\S 710$ is much more complex.

Since GP is treated as receiving compensation, it might appear logical to tax P's income entirely to LP, with an offsetting compensation deduction. ${ }^{82}$ Section 710 does not follow that logical approach: it alters the character of the income allocated to GP but does not reallocate income between GP and LP. ${ }^{83}$ Since LP is taxed on only $80 \%$ of the partnership income, LP receives the equivalent of a deduction in the form of a reduced share of capital gain. ${ }^{84}$ If LP is tax exempt, LP is indifferent to the loss of a worthless deduction. If LP is a taxable individual and the expense is immediately deductible, $\S 710$ is potentially punitive. The net detriment to LP is equal to the difference between the ordinary income rate and the capital gain rate on the implicit salary. Section 710 essentially provides an election to obtain a deduction for GP's implicit salary. To take advantage of this election, the parties must simply pay cash (rather than carry) to GP. This elective workaround exposes a fundamental flaw: under $\S 710$, it is not possible to ensure consistent treatment of the parties regardless of whether cash or carry is used. ${ }^{85}$

81. Any net income is generally treated as ordinary income attributable to services; any net loss is generally treated as ordinary loss to the extent of amounts previously taxed as ordinary income. See Prop. § 710(a)(1)(A) and (B); see also Prop. § 710(c)(2)(C)(iii)(II) (2009) (reduction for net losses and distributions). The loss limitation would be layered on top of existing loss limitation rules. See I.R.C. $\S \S 704(d), 465,469$, and 470 (2009).

82. When $\S 707(\mathrm{a})(2)(\mathrm{A})$ applies, the defective allocation is disregarded and the related items of income (or loss) are reallocated to the other partners, who may also be entitled to a current (or capitalized) deduction for compensation. See JOINT COMM. ON TAX'N, 98TH Cong. 2D Sess., General Explanation of the Revenue Provisions of the Deficit Reduction Act of 1984, 227-28 (Comm. Print 1984); S. Prt. No. 98-169, at 227-29 (1984); H.R. REP. No. 98-432, at 1218-20 (1984) (Conf. Rep.). It is not clear how Prop. § 710 would be coordinated with $\S 707(\mathrm{a})(2)(\mathrm{A})$.

83. See Schler, supra note 13, at 838-39 (contrasting the recharacterization/exclusion approach with the inclusion/deduction approach). Under current law, taxable individual investors' share of capital gain is partially offset by capital gain shifted to the service partner as compensation for investment services. See Knoll, supra note 6, at 157-58 (noting that investors are taxed like any other investor in a capital asset).

84. Denial of a deduction to the investors may be justified on the ground that it "avoids the situation in which individual investors get the tax benefit of concurrent capital gain income and an ordinary deduction." Gergen, supra note 12, at 149 n.2. See also Knoll, supra note 6, at 157 (allowing an ordinary deduction would potentially convert "private equity limited partnership interests [into] tax-advantaged assets").

85. While the option of paying cash to GP offers "a cheap and easy design around" the proposed legislation, there are no practicable alternatives to prevent such self-help measures. 
It is useful to compare the recharacterization approach of $\S 710$ with the entity approach of $\S 707(\mathrm{a})(2)(\mathrm{A})$ which would treat the partnership as paying compensation to GP as a third-party service provider. Under the inclusion/deduction approach of $\S 707(\mathrm{a})(2)(\mathrm{A})$, LP would include P's entire income and would deduct (or capitalize) the implicit salary. ${ }^{86}$ When GP's implicit salary is capitalized, taxing LP on only $80 \%$ of overall gain achieves roughly the same result as under $\S 707(a)(2)(A) .{ }^{87}$ Under the $\$ 707(\mathrm{a})(2)(\mathrm{A})$ approach, LP would be forced to include all of P's income with a potential offsetting deduction. By contrast, the $\S 710$ approach omits the final step of forcing LP to deduct or capitalize the expense. If the implicit salary would be a disallowed expense, the recharacterization/exclusion approach of $\S 710$ treats LP too generously by giving LP the equivalent of a deduction. ${ }^{88}$ The net result is that $\S 710$ will often result in unwarranted bonuses or penalties, subject to transactional elections to vary the results to minimize the parties' joint taxes.

When LP is tax exempt (or otherwise tax indifferent), § 710 eliminates the joint-tax windfall resulting from conversion of ordinary income into capital gain. ${ }^{89}$ Under current law, both GP and taxable individual LPs have an incentive to structure compensation as carry rather than as a fee to avoid the $\S 212$ limitation on the deductibility of investment-type expenses. ${ }^{90}$ If expenses passed through to individual taxable investors are properly treated as $\S 212$ expenses, they may result in

Gergen, supra note 12, at 140; $c f$. id. (suggesting treating compensation contingent on profits "as an allocation of those profits however the payment is formally characterized").

86. Both $\S 707$ (a) payments and $\S 707$ (c) payments are subject to the capitalization requirement of $\S 263$. If the partnership is required to capitalize a salary payment (or the deduction is disallowed), $\S 707(\mathrm{a})(2)(\mathrm{A})$ prevents conversion of long-term capital gain into ordinary income. For example, assume that $\mathrm{P}$ has $\$ 100$ of long-term capital gain, of which $\$ 20$ is taxed to GP. If the $\$ 20$ of implicit salary is capitalized, P's deduction is eliminated, leaving LP with $\$ 80$ of long-term capital gain (\$100 less $\$ 20$ basis offset) and GP with $\$ 20$ of ordinary income.

87. See Knoll, supra note 6, at 128 n.78 (discussing uncertainty under current law concerning whether investment fees (paid in cash upfront) would be deductible immediately or capitalized and amortized over time); Sanchirico, supra note 5, at $1076 \mathrm{n} .13$ (assuming fees would be immediately deductible); Weisbach, supra note 14, at 732 (concluding that payments "would not likely have to be capitalized").

88. Cf. Sanchirico, supra note 5, at 1127 (noting that permanent disallowance is unlikely, since the partnership's business can be restructured to ensure that "the limited partner is able at some point to deduct at least some portion of his distributive share" of the imputed salary expense) (emphasis added).

89. Since corporate partners do not benefit from lower capital gains rates, they are generally indifferent between an ordinary income deduction and reduced capital gain. See Sanchirico, supra note 5, at 1124-25; Knoll, supra note 6, at 130.

90. See I.R.C. § 212 (2009) (treating investment expenses of individual taxpayers as additional itemized deductions). 
a worthless itemized deduction. ${ }^{91}$ By allowing a deduction-equivalent to LP, $\S 710$ attempts to "finesse" the $\S 212$ issue. 92 While overly generous, this approach could be viewed as "simplifying" the treatment of taxable individual investors by not forcing them to include an additional amount in income (their portion of GP's implicit salary) and then claim an offsetting deduction. Although some commentators have suggested that the $\S 212$ limitation may be difficult to defend as a matter of tax policy, taxable individual investors should not be allowed an undeserved windfall. ${ }^{93}$ Even if the partnership claims to be conducting an active trade or business, investment-type expenses attributable to a limited partnership interest, by analogy to a security, should arguably be treated as $\S 212$ expenses.

\section{B. Joint-Tax Perspective and $\$ 83$}

Although some reformers claim that the existing treatment of partnership profits interests is fundamentally untenable as a policy matter, this issue may be a "red herring." 94 The tax treatment of profits interests appears anomalous mainly if one focuses narrowly on GP's one-sided conversion and deferral. From a joint-tax perspective, the existing

91. See I.R.C. $\S \S 67,68$, and 56(b) (2009). If the partnership qualifies as a "trader" rather than an "investor," $\S 162$ may apply to management expenses passed through to investors. $C f$. Rev. Rul. 2008-39, 2008-2 C.B. 252 (management fees paid by upper-tier partnership were not $\S 162$ expenses; fees passed through to investors as separately-stated $\S$ 212 expenses). Even if the partnership is a trader, the $\S 469$ passive loss limitations may apply to an individual investor. See I.R.C. § 469 (2009).

92. Gergen, supra note 12, at 140 ("Code Sec. 710 tries to finesse this issue."). Since "many of the funds targeted by the [legislation] do not engage in a "trade or business' at all," the proposed legislation is clearly overly generous to investors. NYSBA Report, supra note 11 , at 69 n. 184 .

93. Cf. Sanchirico, supra note 5, at 1105 (suggesting that avoidance of the $\S 212$ limits may be "quite different normatively" since the disfavored treatment of investment expenses "is not itself easy to justify as a policy matter"). While managers' outsized salaries may be an especially attractive target for reform, the case for preserving taxable individual investors' current favorable treatment needs to be made explicitly, not as a backhanded criticism of $\S$ 212. See Susan Kalinka, Rev. Rul. 2008-38 and Rev. Rul. 2008-39: Above the Line, Below the Line and Even Further Below the Line, 87 TAXES 23 (2009) (proposing to treat all passive investors the same whether they invest in securities directly or through a hedge fund); Andrew W. Needham \& Christian Brause, 736 B.N.A. TAX Mgmt. PortFolio A-59 to A-63 (2007) (discussing uncertainties concerning a hedge fund's "trader" status).

94. Sanchirico, supra note 5, at 1082 (describing flawed tax treatment of profits interests as "something of a red herring"). Whatever its defects, current law is clearly rooted in considerations of administrability, not an intent to "subsidize activity carried out in the partnership form." Ronald J. Gilson \& David M. Schizer, Understanding Venture Capital Structure: A Tax Explanation for Convertible Preferred Stock, 116 HARV L. REV. 874, 913 (2003). 
treatment of partnership profits interests generally does not give rise to a tax advantage (or disadvantage) if all parties are taxed at the same rates on ordinary income and capital gains. It is important to consider the tax treatment of partnership profits interest within the broader spectrum of alternative compensation arrangements. The differing tax treatments of these alternative compensation forms can be illustrated graphically as follows:

\begin{tabular}{|l|l|l|}
\hline \multicolumn{2}{|l|}{ GP's Profits Share } \\
\hline & GP & LP \\
\hline $\begin{array}{l}\text { Profits interest } \\
\text { (current law) }\end{array}$ & GG (realization) & no deduction \\
\hline Option & OI (exercise) & $\begin{array}{l}\text { CG (realization) } \\
\text { ordinary deduction (exercise) }\end{array}$ \\
\hline$\S 710$ & $\begin{array}{l}\text { OI (realization) } \\
\text { CG (realization) }\end{array}$ & no deduction \\
\hline$\S 707($ a)(2)(A) & OI (distribution) & $\begin{array}{l}\text { CG (reallocation) } \\
\text { ordinary deduction (payment) }\end{array}$ \\
\hline
\end{tabular}

From a joint-tax perspective, profits interests and options are generally not tax advantaged when LP and GP are taxed at the same rates. In the case of a profits interest, the tax benefit to GP, who reports capital gain rather than ordinary income as partnership profits are realized and allocated, is precisely offset by the tax detriment to LP, who reports less capital gain but loses an ordinary deduction. ${ }^{95}$ From a joint-tax perspective, a compensatory partnership option is not globally tax advantaged because GP's entire compensatory return is taxed as ordinary income, offset by a deduction to LP, and the partnership's entire investment return is taxed to LP. Similarly, under the Service's administrative guidance for valuing a profits interest upon receipt, there may be no joint-tax advantage if both LP and GP are taxed at the same rates. ${ }^{96}$ If LP is tax exempt (or otherwise tax

95. See Sanchirico, supra note 5, at 1076, 1082 (concluding that the tax advantage enjoyed by private equity fund managers "is most fundamentally a form of "joint-tax arbitrage"" rather than "a matter of wholesale conversion and deferral"); Knoll, supra note 6, at 128; Weisbach, supra note 14, at 732-33 ("[T] he only real difference between use of an explicit salary and the use of a carried interest relates to having tax-exempt investors.").

96. One commentator has recently faulted reformers for failing to identify the $\S 83(\mathrm{~b})$ election as a source of inequity in the taxation of equity-based deferred compensation. See Philip F. Postlewaite, Fifteen and Thirty Five - Class Warfare in Subchapter K of the Internal Revenue Code: The Taxation of Human Capital Upon the Receipt of a Proprietary Interest in a Business Enterprise, 122 TAX NOTES 503, 531 (2009). From a joint-tax perspective, however, a $\S 83$ (b) election is likely to be tax advantageous only if the employer 
indifferent), however, the fundamental premise of safe harbor treatment is flawed, since LP suffers no offsetting detriment in the form of a forgone compensation deduction. ${ }^{97}$

As discussed below, the Service's liberal administrative guidance on profits interests was arguably never intended to sanction the type of capital-gain conversion that prompted reformers' ire. Rather, safe harbor treatment should be limited to those situations in which there is little room for abuse because sufficient tax tension exists between the partners. Ironically, it was quite clear to sophisticated partnership practitioners, though perhaps not to Congress, that private equity arrangements were not literally protected under the Service's administrative guidance. On the one hand, practitioners perhaps hoped and believed that regulations proposed in 2005 (and never finalized) would retroactively sanction the aggressive position that receipt of such carried interests was tax free. On the other hand, reformers demanded a statutory solution to a problem flowing from overly generous administrative rules that never had the force of law. If the problem was administrative in nature, however, the solution may well be for Congress to direct Treasury to use existing regulatory and statutory tools to address the underlying problem.

While generally following the Service's prior administrative guidance, the 2005 proposed regulations impose formal conditions concerning the taxation of profits interests more consistent with the general structure of $\S 83 .^{98}$ Under the proposed regulations, two elections must be made to ensure partner status: an election to treat the value of the interest (capital or profits) as equal to the amount the service provider would receive on an immediate deemed liquidation of the partnership (the liquidation-value election) and an election to include the value of a nonvested interest in income (a $\S 83(\mathrm{~b})$ election). ${ }^{99}$ The proposed regulations sanction nonrecognition of gain or loss at the partnership level when a partnership transfers a compensatory partnership interest or

is effectively tax-exempt; in this situation, "the parties can generate a large tax benefit from undervaluing the employer's shares and making the election." See Knoll, supra note 5, at 745.

97. While the lack of any offsetting tax detriment should be sufficient grounds to exclude such arrangements from safe harbor treatment, current law may present a closer issue. See Staff of the Joint Comm. on Tax'n, Present Law and Analysis Relating to Tax Treatment of Partnership Carried Interests and Related Issues 54 (Sept. 4, 2007) (JCX 6207) (querying "whether it is appropriate to permit the general partner to have favorable tax treatment premised on an offsetting tax disadvantage to limited partners when, by virtue of the limited partners' tax status, no such disadvantage results.").

98. See REG-105-346-03, supra note 32, Preamble. Under the proposed 2005 regulations, the liquidation-value election is available only if services are performed for the issuing partnership.

99. See id. 
option. ${ }^{100}$ Under the so-called "circle-of-cash" theory, the partnership may be deemed to transfer cash compensation to the service partner who then recontributes the cash to the partnership in exchange for a capital interest. The 2005 proposed regulations do not explicitly adopt the circle-of-cash theory; without any analysis or discussion, the preamble states merely that deferring partnership-level gain is "more consistent with the [nonrecognition] policies underlying section 721" than would be a recognition rule. ${ }^{10}$

The 2005 proposed regulations were controversial because they contradicted prior authority that was generally viewed as requiring nonservice partners to recognize gain on exchange of a partnership capital interest for services. ${ }^{102}$ While the partnership tax bar has generally extolled the nonrecognition result-by analogy to $\S 1032$ when a corporation transfers stock as compensation for services-such treatment is surprisingly difficult to reconcile with the legislative history and statutory structure of $\S 721 .{ }^{103}$ Thus far, the carried interest legislation does not address the controversial issue of partnership-level gain recognition when a service partner receives a capital interest (or exercises a compensatory option). ${ }^{104}$ Now that $\S 710$ has implicitly reopened these issues, however, it seems

100. See Prop. Reg. § 1.721-1(b)(2), 70 Fed. Reg. 29675 (May 24, 2005). If the partnership revalues its assets in connection with the service partner's admission, built-in gain or loss in the partnership's assets is preserved, under $\S 704(\mathrm{c})$ principles, for later recognition by the non-service partners. See Treas. Reg. $\S 1.704-1(\mathrm{~b})(2)(\mathrm{iv})(f)(5)(\mathrm{iii})$ (as amended in 2008); see also Treas. Reg. § 1.704-1(b)(4)(i) (as amended in 2008).

101. REG-105-346-03, supra note 32, Preamble.

102. Under the prevailing view prior to issuance of the proposed 2005 regulations, transfer of a capital interest in exchange for services results in recognition of gain or loss at the partnership level. See, e.g., YIN \& BURKe, supra note 74, at 278. The partnership is allowed a deduction (allocated to the non-service partners) equal to the amount included in the service partner's income. See Treas. Reg. § 1.83-6(a)(1), (a)(4) (as amended in 2003) (capitalization requirement).

103. See generally Martin J. McMahon, Recognition of Gain By a P'Ship Issuing an Equity Interest, 109 TAX NOTES 1161 (2005) (arguing that nonrecognition treatment is inconsistent with the legislative history of $\S 721$ ); $c f$. Douglas A. Kahn, The Proper Treatment of the Transfer of a Compensatory Partnership Interest, 62 TAX LAW. 1, 51-56 (2009) (criticizing McMahon's view).

104. See Monte A. Jackel \& Robert J. Crnkovich, Partnership Deferred Compensation and Carried Interests, 123 TAX NOTES 351, 353 (2009). A prior version of Prop. $\S 710$ required partnership-level gain recognition on a distribution of appreciated property to a service partner, but the provision was revised to limit gain recognition solely to the service partner. See Carol Kulish Harvey \& Eric Lee, A Technical Walk Through the Carried Interest Provisions Contained in Chairman Rangel's Tax Reform Proposal, 86 TAXES 77, 93 (2008) (discussing former version of Prop. § 710(b)(4)); NYSBA Report, supra note 11, at 31-32. As the partnership tax bar clearly perceived, partnership-level gain recognition under Prop. $\S 710$ would have been inconsistent with the proposed 2005 regulations which defer the historic partners' gain recognition on transfer of a capital interest for services. 
likely that the partnership tax bar may seek the opportunity to obtain a statutory override to the gain recognition rule. If so, $\S 710$ may become the excuse for achieving yet another longstanding goal of the partnership tax bar-namely, to create a special nonrecognition rule for partnerships when property is transferred in exchange for services.

In response to comments from the partnership tax bar, the carried interest bill would significantly amend $\S 83 .{ }^{105}$ The revision to $\S 83$ is very brief and essentially adds two special rules for partnership interests distinct from all other types of property subject to $\S 83$. First, except as provided by regulations, the fair market value of a partnership interest issued for services (whether a capital or profits interest) would be treated as equal to the liquidation value of the interest (as determined under a hypothetical sale at the time of grant). Second, the recipient of the interest would be deemed to make a section 83(b) election unless the recipient specifically elected not to have section 83(b) apply. The net effect of these changes is that the recipient of a nonvested profits interest would obtain all of the benefits of partner status at no tax cost, without even bothering to make a $\S 83(\mathrm{~b})$ election. Such largesse would no longer depend on dubious administrative guidance but would instead be codified as an amendment to $\S 83$.

Since a compensatory partnership interest is nearly always structured as a profits interest (rather than a capital interest), the deemed $\S$ 83(b) election achieves a taxpayer-favorable result (zero value), subject to an election out. ${ }^{106}$ In the unlikely event that the service partner receives a capital interest, the liquidation-value rule prevents "whipsawing" of the government: the recipient could not claim a lower discounted value based on fair market value, while non-service partners claimed a deduction (or capitalized expense) based on the higher liquidation value. ${ }^{107}$ The proposed rules are extraordinarily favorable to taxpayers who would nearly always prefer to structure compensation as a nontaxable profits interest rather than a taxable capital interest. Indeed, if there were any serious likelihood that a compensatory interest would be structured as a capital interest, the

105. Proposed $\S 83(\mathrm{a})(4)(\mathrm{A})$ and (B) contained in Section 1 of the Levin Bill, supra note 1. See NYSBA Report, supra note 11, at 8 (recommending amendment of $\S 83$ to permit or require use of liquidation value).

106. In effect, the deemed election would free service partners and non-service partners from the burden of making two elections: a liquidation-value election and a $\S 83(\mathrm{~b})$ election. See NYSBA Report, supra note 11, at 27-28 (suggesting "a clear statutory basis for liquidation value" is necessary to allow partnerships to make the liquidation-value election on behalf of partners "free of the procedural constraints of the currently-proposed safe harbor").

107. While a profits interest has a liquidation value of zero by definition, the liquidation-value of a capital interest may exceed its fair market value discounted to reflect lack of marketability and other factors. 
partnership tax bar would presumably demand valuation discounts to reflect lack of marketability and control.

Formally, receipt of a compensatory partnership profits interest would continue to be subject to $\S 83$. Nevertheless, the zero-value rule and deemed $\S$ 83(b) election would effectively exempt partnership profits interests from entanglement with $\S 83$. Since 1969, much of the partnership tax bar has strenuously resisted the notion that $\S 83$ should apply in the partnership area. ${ }^{108}$ As William McKee noted in 1977, the "potential conflict between $\S 83$ and Subchapter $\mathrm{K}$ is more than skin-deep ... . [T]reating a person as a partner prior to the lapse of a substantial risk permits the $\S 83$ scheme to be subverted and manipulated to the advantage of a canny taxpayer."109 Indeed, McKee recommended a "compromise solution" under which the normal partnership rules would "simply give way to $\S 83$, so that all income included in the distributive share of a partner [whose interest is forfeitable] would be treated as compensation income, regardless of its character as determined at the partnership level."110 Proposed $\S 710$ is strikingly similar to McKee's compromise proposal, but would often afford even more taxpayer-friendly treatment by recharacterizing some (but not all) of a profits share as ordinary income. ${ }^{111}$

As a policy matter, the issue is whether profits interests should be exempt from the normal rule of $\S 83$ applicable to all other transfers of property for services. The zero-value rule provides an unjustifiable valuation subsidy to recipients of profits interests in comparison to other types of non-partnership equity compensation. ${ }^{112}$ Since enactment of $\S 83$, Congress has codified the rules for taxing deferred compensation under $\S$ 409A, which applies in both the corporate and partnership contexts. ${ }^{113}$ The

108. E.g., William S. MCKeE et al., Federal TAXation of Partnerships and PARTNERS $9.08[3]$ [a] at 5-44 to 5-45 (1977) (referring to $\S 83$ as "inspired primarily by dissatisfaction with prior law relating to transfers of corporate stock to employees" and warning of "unexpected consequences" if applied to transfers of partnership interests). For a contemporary view of $\S 83$ along similar lines, see Abrams, supra note 2, at 208-11, 221.

109. MCKEE, supra note 108, at $95.08[3][\mathrm{b}]$ at 5-50.

110. Id. at 5-50 to 5-51.

111. Although McKee's proposal applied only to a forfeitable interest, a profits interest contingent on a performance goal is forfeitable under $\S 83$. See Treas. Reg. $\S 1.83-3(c)(1)$ (as amended in 2005).

112. See Gilson \& Schizer, supra note 94 , at 907-09 (noting that current rules immunize aggressive valuation for safe harbor interests). Cf. Postlewaite, supra note 96, at 515 (claiming that "the tax treatment of a profits interest is neither unique nor extraordinary.").

113. If $\S 409 \mathrm{~A}$ applies, deferred compensation may be required to be included in income prior to the year of payment; in addition, the deferred income may be subject to a $20 \%$ exercise tax and interest charges. See I.R.C. $§ 409$ A(1)(A) and (B) (2009). Profits interests do not typically limit rights to receive distributions in a manner that would satisfy the requirements of $\S$ 409A. See Carman, supra note 13, at 115. 
$\S 409$ A regulations treat the valuation of illiquid stock in a start-up corporation as reasonable only if the fair market value is determined under a reasonable valuation method that takes relevant factors into account. ${ }^{114}$ Under these valuation guidelines, the liquidation-value methodology is patently unreasonable: it ignores factors relevant to valuation and creates a fictional liquidation that bears no relationship to the parties' intent. This fictional approach may well encourage misvaluation in related areas in which the liquidation-value methodology would be clearly abusive. ${ }^{115}$ If the concern is merely to coordinate $\S 710$ with existing law, a much narrower fix should suffice that would not override the general principles of $\S 83$ in the partnership context. ${ }^{116}$

Since $\S 83$ was added in 1969 , Congress has enacted significant legislation-including § 409A and most recently § 457A-accelerating income and imposing penalties in the case of certain deferred compensation arrangements. ${ }^{117}$ These complex provisions potentially impact the treatment of compensatory profits interests and amounts recharacterized as ordinary income under proposed $\S 710 .^{118}$ If Congress proceeds further with the carried interest legislation, it will be necessary to consider carefully the interactions between these provisions and $\S 710$. More broadly, the issue is whether a compensatory partnership interest should be treated like other property for purposes of $\S 83$ and related provisions governing deferred compensation arrangements. Since the current entity classification rules greatly narrow the substantive differences between partnerships and corporations, it is not clear why profits interests should be treated so differently from nonqualified stock options which they

114. See Treas. Reg. § 1.409A-1(b)(5)(iv)(B)(1) and (2) (2007).

115. See, e.g., Gilson \& Schizer, supra note 94, at 908 n.113 (suggesting possibility of "wrapping" a corporation in a partnership); Karen C. Burke \& Grayson M.P. McCouch, Family Limited Partnerships: Discounts, Options, and Disappearing Value, 6 Fla. TAX. REV. 649, 671-72 (2004) (noting that "value .. . disappears from the transfer tax base under existing law as a result of inconsistent valuation assumptions").

116. See Prop. $\S 710(\mathrm{c})(2)(\mathrm{C})$. If both Prop. $\S 710$ and $\S 83$ apply, the concern is apparently that the fair value of a profits interest could potentially be taxed twice. See ABA Comments, supra note 11, at 16-17. Alternatively, the concern may be that the liquidationvalue presumption is inconsistent with the language of $\S 83$ concerning the "fair market value" of an interest. See Harvey \& Lee, supra note 104, at 98, 102 n.97.

117. I.R.C. $\S 457 \mathrm{~A}$ addresses deferral of compensation paid by a tax-indifferent party (such as a foreign corporation located in a tax haven whose income is not subject to U.S. tax). In this situation, deferral of the service-provider's income is not offset by any tax detriment to the payor.

118. The Levin bill no longer provides that recharacterized income will be treated as compensation for performing services. See Carol Kulish Harvey \& James B. Sowell, Proposals on Carried Interests, Business EnTITIES 4, 10 n.22 (July/August 2009) (suggesting that this change may be intended to "ameliorate" problems that could otherwise arise under $\S \S 409 \mathrm{~A}$ and $457 \mathrm{~A}$ ). 
resemble. $^{119}$

In summary, there has been virtually no public discussion of the proposed amendment to $\S 83$ based on the partnership tax bar's recommendations. While the proposed amendment may be portrayed as merely codifying the Service's prior administrative guidance, it overrides general $\S 83$ principles applicable to all other transfers of property for services. If the Service's prior administrative guidance was excessively lenient and arguably helped to give rise to the carried interest problem, the solution should not be to codify such guidance in the guise of reform. Allowing easy access to partnership status for profits holders who own option-like interests will only lead to yet more complicated partnership rules to prevent abusive trading of tax characteristics. Such complexity will inevitably spill over into routine non-abusive transactions while rendering Subchapter K even more inaccessible and opaque except to highly-skilled partnership tax specialists who have the ability to exploit intricate rules for the benefit of their clients. Safe harbor treatment for profits interests should be reserved for non-abusive arrangements in which the tax tensions between the partners provide an adequate safeguard against joint-tax minimization.

\section{Compensatory Options Versus Profits Interests}

Because partnership profits interests and options are often close economic substitutes, it is useful to consider how $\S 710$ might affect the choice between these alternative forms of compensation. Under current law, profits interests are typically viewed as more tax efficient than compensatory partnership options. ${ }^{120}$ Even though the profits holder is taxed currently on his share of partnership income, the character of the income may be capital rather than ordinary. By contrast, the option holder defers taxation until exercise of the option but is taxed entirely on ordinary income at the time of exercise. If $\S 710$ operates as intended, however, it would eliminate the profit holder's benefit of capital-gain conversion, without altering the timing of income recognition. Section 710 would thus dramatically alter the relative tax efficiency of these alternative forms of compensation. $^{121}$ A profits holder would be taxed sooner than an option

119. See Treas. Reg. $\S \S 301.7701-2$ (as amended in 2009), 301.7701-3 (as amended in 2007) (elective classification of eligible business entities as corporations or partnerships).

120. See generally James Sowell, Partners as Employees: A Proposal for Analyzing Partner Compensation, 90 TAX NOTES 375 (2001) (discussing use of options to ensure employee status).

121. Proposed $\S 710$ apparently does not apply to a compensatory option to acquire a partnership interest. See Prop. $§ 710$ (d) (disqualified interests); Schler, supra note 13, at 852 
holder but would no longer enjoy any conversion benefit. An option should thus prove relatively more tax-efficient than a profits interest, since the service provider would defer recognition of ordinary income until exercise of the option and all interim investment return would be taxed solely at LP's zero rate. ${ }^{122}$ Sensibly, the parties should opt out of $\S 710$ if option treatment produces a better joint-tax result.

Example (3)-European Option Alternative. Building on the same facts in Example (1), assume that GP's profits interest is restructured as a European option exercisable immediately prior to liquidation of $\mathrm{P}$. The receipt of the option is tax free, since the option lacks a readily ascertainable fair market value. ${ }^{123}$ Under current law, tax-exempt LP is taxed on P's entire gain of $\$ 5$ million realized prior to exercise of the option, since GP is not treated as a partner. Upon exercise of the option, GP recognizes ordinary income of $\$ 1$ million (the liquidation value of GP's acquired capital interest) and LP receives a worthless ordinary income deduction (or offsetting capital loss) to reflect the compensation paid to GP. ${ }^{124}$ Since LP is tax exempt, the investment return on P's assets is entirely untaxed and GP defers recognition of ordinary income until liquidation.

From GP's perspective, a compensatory option is tax advantaged because it permits deferral of the tax (the equivalent of yield exemption) until exercise of the option. ${ }^{125}$ If GP instead received a profits interest and were taxed under $\S 710$, GP would be taxed on $\$ 1$ million of ordinary income in Year 2 equal to GP's 20\% share of P's $\$ 5$ million of gain. Thus, profits treatment would accelerate the ordinary income tax on GP's compensation even though GP's carry is not actually earned until Year 5. If the goal is to minimize the parties' joint-tax liability, the most sensible strategy would be to treat GP as an option holder, so that all investment return is taxed at LP's zero rate. Stated differently, structuring GP's compensation as a profits interest in Example (1) saves taxes only because

(noting confusion concerning application of Prop. § 710(d) to options to acquire stock).

122. The proposed 2005 regulations request comments concerning whether an antiabuse rules is needed in such circumstances. See REG-105-346-03, supra note 32, Preamble, $\S 1$.

123. See Treas. Reg. $§ 1.83-7$ (a) (as amended in 2004).

124. LP's basis is initially increased to $\$ 45$ million ( $\$ 40$ million plus $\$ 5$ million gain); if the expense were capitalized, LP would recognize a $\$ 1$ million capital loss (\$44 million distribution less $\$ 45$ million basis) upon liquidation.

125. GP is treated in the same manner as an employee who receives a nonqualified stock option (NQSO) and defers ordinary income from grant until exercise of an option. See Walker, supra note 5, at 711 (positing an employee's "hypothetical outside investment in an NQSO" and noting that "deferral effectively eliminates the tax on the outside investment return"). 
it allows conversion of GP's salary into capital gain. If conversion is no longer possible under $\S 710$, an option minimizes joint taxes because it allows yield exemption and longer deferral.

As illustrated in Example (1), current-law profits treatment also allows GP to borrow interest-free from LP, subject to a potential clawback of unearned carry. In terms of the partners' economic arrangement, a European option is not economically equivalent to a profits interest unless GP can borrow explicitly (without interest) from LP to replicate the cashflow consequences of early distributions. If GP borrows explicitly from LP, the "loan" may be treated as a below-market interest loan under $\S$ $7872 .{ }^{126}$ GP would have imputed income (the foregone interest) potentially offset by an imputed interest deduction (the deemed interest payment). ${ }^{127}$ If the interest income and deduction offset each other, the net result is that GP defers recognition of ordinary income until liquidation, when GP exercises the option and repays the loan principal. ${ }^{128}$ Thus, GP may be able to replicate the cash-flow consequences of profits treatment if the arrangement is restructured as an option coupled with an explicit (rather than implicit) loan.

Taxing GP upon exercise of a European option is equivalent to taxing GP's compensation as a nonpartner payment under $\S 707(\mathrm{a})(2)(\mathrm{A})$ and deferring inclusion until distribution. ${ }^{129}$ Setting aside the issue of capital-gain conversion, deferral of GP's income inclusion is essentially no different from the result that GP could obtain through a contractual deferred compensation arrangement, as long as GP is willing to incur a substantial

126. Section 7872 applies to a below-market loan between an employer and an employee or between an independent contractor and the person for whom such contractor provides services. See I.R.C. $\S 7872$ (c)(1)(B) (2009). It also applies to a below-market loan between a "partnership and a partner . . . acting other than in his capacity as a member of the partnership." Prop. Treas. Reg. § 1.7872-4(c)(1), 50 Fed. Reg. 33553, 33560 (Aug. 20, 1985). See also Prop. Treas. Reg. $\S 1.7872-4(e), 50$ Fed. Reg. 33553, 33561 (Aug. 20, 1985) (tax-avoidance loan).

127. If applicable, the investment interest limitation under $\S 163(\mathrm{~d})$ could limit GP's ability to obtain an ordinary income deduction for the deemed payment of interest. See I.R.C. $\S 163(d)$ (2009). See also I.R.C. § 163(d)(4)(B)(iii) (2009) (affording election that effectively permits the deduction for investment interest to offset only gain taxed at the $15 \%$ rate). If GP is treated as using the deemed loan principal in a trade or business or has sufficient "net investment income" from other sources, the $\S 163(\mathrm{~d})$ limit is not binding. See Sanchirico, supra note 5, at $1141 \mathrm{n} .181$.

128. Of course, an explicit loan from LP to GP might expose implicit subsidies embedded in the opaque distribution rules when a profits interest is used. See supra notes 57-61 and accompanying text.

129. Under current law, GP is likely not treated as having constructively received amounts that are merely credited to his capital account, unless GP has a right to withdraw such amounts immediately. See, e.g., Rev. Rul. 60-31, 1960-1 C.B. 174. But see I.R.C. § 707(c) (2009) (potentially accelerating the timing of GP's inclusion). 
risk of forfeiture. ${ }^{130}$ Indeed, GP could obtain the same deferral benefit if he received a restricted capital interest, since the partnership's investment return prior to vesting of GP's interest would be taxed entirely to LP. In this light, it is strange that Congress should enact a complex statutory fix while allowing the parties freely to opt out of $\S 710$ to minimize their jointtax liability when LP is tax-exempt.

By focusing narrowly on GP's one-sided deferral and conversion, reformers failed to consider the ready availability of deferral through alternative compensation arrangements such as options and restricted capital interests. Although $\S 710$ could conceivably be viewed as an antideferral provision, this view does not make sense if alternative compensation arrangements permit yield exemption and even longer deferral than profits interests. As a practical matter, the parties should opt in or out of $\S 710$ depending on whether that provision minimizes taxes by comparison to alternative compensation forms. To understand the joint-tax incentives under $\S 710$, it is essential to understand the operation of the earned capital exception when implicit salary is reinvested in the enterprise and distributions are deferred.

\section{EARNED CAPITAL - THE BIFURCATION APPROACH}

Unlike the manager of a private equity fund, service partners in traditional partnerships typically receive cash distributions only after the investor partners' capital has been repaid. When a service partner receives implicit salary and leaves the previously taxed salary in the partnership, the service partner's share of partnership capital will increase each year. Indeed, the full complexity and unadministrability of $\S 710$ only becomes apparent once one examines the partnership tax bar's technical solution to the problem of earned capital that Congress initially overlooked. Under this bifurcation approach, a single profits stream would be divided annually into separate components consisting of labor return and investment return on reinvested implicit salary. The partnership tax bar has devised a truly ingenious and wonderfully complex solution that purports to disentangle the separate components of a service provider's return: a service provider would be taxed on a constantly shifting mix of ordinary income from labor and capital gain from labor converted into earned capital. Unfortunately, the existing capital account system is wholly inadequate to prevent

130. See Sanchirico, supra note 5, at 1131-33 (discussing deferral alternatives); id. at 1133 (suggesting the strictures of $\S 409 \mathrm{~A}$ are "orthogonal" to the carried interest debate because they are only intended to affect "attempts to end run the requirement [that the] promise of future payment remain subject to creditors' claims"). 
understatement of compensatory return (and overstatement of investment return), and the government lacks resources to police self-serving misvaluations. The preferable approach, assuming $\S 710$ is enacted, would be to treat a service partner's entire profits share as ordinary income.

\section{A. Earned Capital}

Section 710 rests on an elaborate fiction: GP is deemed to own qualified capital before GP actually earns such capital under the terms of the partners' economic arrangement. If GP's right to carry is contingent on attainment of a performance goal, profits allocations to GP cannot have substantial economic effect under the $\S 704(\mathrm{~b})$ regulations governing allocation of items of income and loss among partners. ${ }^{131}$ The reason why such allocations cannot have substantial economic effect is quite simple: if the service partner forfeits his interest, he will never bear the burden or receive the benefit of the income and loss allocated to him. Nevertheless, $\S$ 710 treats each allocation of profits to GP as a closed transaction with respect to a portion of GP's profits interest. ${ }^{132}$ Under this closed transaction approach, GP is treated as owning an increasing share of partnership capital from reinvested earnings even though GP may ultimately forfeit such capital. When GP is taxed on implicit salary and leaves the salary in the firm, $\S 710$ treats the arrangement as a cash salary reinvestment plan, analogous to a deferred compensation arrangement in which an employee invests through an employer. ${ }^{133}$

Surprisingly, § 710 did not originally include any exception for earned capital. Quite correctly, the partnership tax bar criticized this omission as inconsistent with distributive-share treatment under the normal rules of Subchapter K. In response to the bar's comments, the current bill expands the definition of qualified capital to include earned capital attributable to retained earnings, thereby increasing the complexity of the partnership rules which are "already formidably complex." ${ }^{\text {"134 }}$ Crediting GP

131. See Treas. Reg. $\S 1.704-1(b)(2)$ (as amended in 2008). Under the 2005 proposed regulations, special allocations to a service partner while his interest remains subject to forfeiture may be deemed to have economic effect if the partners agree to elaborate “forfeiture allocations." Prop. Treas. Reg. § 1.704-1(b)(4)(xii), 70 Fed. Reg. 29675, 29681 (May 24, 2005).

132. By contrast, a dividend on unvested stock (absent a $\S 83$ (b) election) is treated as compensation income. See Treas. Reg. § 1.83-1(a)(1) (as amended in 2003).

133. See Sanchirico, supra note 5, at 1141 (referring to cash salary reinvestment plan); Gergen, supra note 12, at 140 (referring to a "“compensation reinvestment plan' akin to a dividend reinvestment plan").

134. NYSBA Report, supra note 11, at 19; id. at 21 (arguing that the former definition of invested capital was "far too restrictive" and would "grossly overstate" the ordinary 
with earned capital attributable to reinvested salary is a logical corollary of $\S 710$ 's hybrid approach. In the partnership tax bar's view, treating GP's reinvested salary as earned capital simply avoids the need for a taxprompted distribution followed by a contribution of the distributed amount. This rationale may not be quite right, however, since GP's earned capital would not necessarily be burdened with the cost of the carried interest itself. ${ }^{135}$ Rather, the bifurcation approach disaggregates GP's return without having any affect on the other partners. This peculiar approach is a byproduct of the decision to leave LP's treatment unchanged under $\S 710$.

Because GP is entitled to an investment return on reinvested salary, the earned capital exception is central to the operation of $\S 710$. In effect, $\S$ 710 subdivides GP's profits share into separate streams of income and taxes less than GP's entire profits allocation as ordinary income. The disaggregation (or carve out) approach has no counterpart under existing Subchapter K: GP's entire profits share is reduced by the carved out investment return on previously-taxed salary, and only the reduced profits share is taxed as ordinary income. Consistent with the fundamental tradeoff that leaves LP's treatment unchanged, disaggregation affects only the character of GP's overall return (not the actual dollars received by GP). Section 710 decomposes GP's profits share into two streams of income, consisting of ordinary income (sourced to GP's profits interest) and an investment return (sourced to reinvested salary). ${ }^{136}$ Over time, a portion of P's investment return is shifted from LP to GP, as GP acquires an increased proportional interest in partnership capital attributable to retained earnings.

\section{B. Cash Salary Reinvestment Plan}

Taxing the compensatory and investment components of a service

income element of a service partner's interest). The earned capital exception can be viewed as simply an extension of the broader problem of determining proportionality when a service partner acquires both a capital interest and a disproportionate profits interest.

135. See Harvey \& Sowell, supra note 118, at 9 n. 20. If GP actually "purchased" an additional capital interest in $\mathrm{P}$ by reinvesting salary, the consequences would be as follows: (1) LP would be entitled to $80 \%$ of P's entire investment less $x \%$ attributable to GP's newlyacquired interest, (2) GP's $x \%$ of the investment return would be stacked on top of GP's undiminished profits share and (3) GP would be treated as paying salary to himself. Clearly, the parties do not intend this result.

136. Unless GP is treated as having two separate partnership interests, the concept of earned capital makes little sense. Nevertheless, Prop. $\S 710$ retains the concept of a unitary partnership basis. See Joel Scharfstein, Proposed Carried Interest Legislation: The Interaction of Invested Capital and Book-Ups, 87 TAXES 151, 153 (2009) (proposing an approach under which a service partner would be treated as having "two interests, a pure invested capital interest and a pure noninvested capital interest"). 
partner's return may be viewed as posing familiar problems of deferred compensation when an employee invests deferred salary through an employer. If GP actually received cash compensation (rather than carry) and reinvested the cash compensation in the partnership, GP would be entitled to an investment return taxed potentially as capital gain. As illustrated below, the imputed cash salary reinvestment plan is equivalent to (1) taxing GP on the discounted present value of GP's implicit salary at ordinary income rates and (2) taxing GP (at GP's rates) on investment gain (otherwise taxable to LP at a zero rate) that accrues on GP's reinvested salary at the rate of return earned by P. Since GP is taxed at a higher rate than tax-exempt LP, shifting investment income from LP to GP should, in theory, be tax disadvantageous. The extra tax burden should be equal to the capital gain tax (at GP's rate) on the shifted investment income that would otherwise be taxed at LP's zero rate. If $\S 710$ actually increases the partners' joint-tax liability, however, the partnership could potentially work around $\S 710$ by substituting an option for a profits interests. If such substitution does not occur, one reason may be that $\S 710$ would provide opportunities to understate the compensation component of GP's return, saving taxes equal to the difference between the ordinary income tax rate $(35 \%)$ and the capital gain rate $(15 \%)$. Stated differently, $\S 710$ could reintroduce similar capital-gain conversion opportunities as under existing profits treatment.

From the government's perspective, $\S 710$ may thus be less advantageous than taxing GP in the same manner as an option holder. Deferring tax until exercise of an option is equivalent to taxing investment return at a zero rate but taxing GP's implicit salary and the earnings on such implicit salary at ordinary income rates. Leaving aside who is taxed on the investment return (LP or GP), option treatment does not permit capital-gain conversion because the total amount received on exercise is taxed at ordinary income rates.

Example (4)-Coinvestment By GP and Government. At the beginning of Year 1, GP and LP form P, an investment partnership. GP receives a $20 \%$ interest in P's profits (with a liquidation value of zero); LP contributes $\$ 100$ and is entitled to the remaining $80 \%$ of P's profits. P's assets double in value each year, and $\mathrm{P}$ realizes gain of $\$ 100$ in Year 1, $\$ 200$ in Year 2, and $\$ 400$ in Year 3. All profits are retained until liquidation of $\mathrm{P}$ at the end of Year 3. Upon formation, LP owns all of P's capital. On December 31, Year 1, P pays implicit salary of $\$ 20$ to GP $(20 \%$ $\mathrm{x} \$ 100$ gain) taxed entirely as ordinary income. In each subsequent year, GP is allocated $20 \%$ of profits ( $\$ 40$ in Year 2 and $\$ 80$ in Year 3). Under the cash salary reinvestment plan, GP is credited with earned capital of $\$ 20$ from GP's share of Year 1 profits; at the rate of appreciation of the 
partnership's assets, GP's earned capital of $\$ 20$ would grow to $\$ 80$ ( $\$ 20$ x 2 $x 2$ ) at the end of Year 3. Thus, GP's share of Year 2 profits is taxed partly as ordinary income $(\$ 20)$ and partly as capital gain $(\$ 20$, i.e., the investment return on GP's unwithdrawn salary from the prior year). GP's share of Year 3 profits is again taxed partly as ordinary income (\$20) and partly as capital gain ( $\$ 60$, i.e., the investment return on GP's unwithdrawn salary from both prior years). ${ }^{137}$

If the tax on GP's salary is deferred, the result is that GP will eventually be taxed at ordinary income rates on the accumulated amount (both the original compensation and investment return) when withdrawn from the partnership. Deferral of the tax means that GP and the government effectively become co-investors in $\mathrm{P}$; as a co-investor, the government should be entitled to $35 \%$ of GP's pretax investment in the partnership. ${ }^{138}$ At the end of Year 1, GP contributes \$13, and the government contributes $\$ 7(\$ 20 \times 0.35)$ to $\mathrm{P}$; together, they own $\$ 20$ of P's total capital of $\$ 200(10 \%)$ and LP owns the remaining $\$ 180(90 \%)$. Since P's assets double in value each year, GP earns an investment return of \$39 (\$13 in Year 2 and \$26 in Year 3) on his invested capital of \$13; and the government earns an investment return of \$21 (\$7 in Year 2 and \$14 in Year 3) on its invested capital of $\$ 7 .{ }^{139}$ At the end of Year 2, GP contributes an additional $\$ 13$ and the government contributes an additional $\$ 7$ (35\% x \$20) to P; together they own \$60 of P's total capital of $\$ 400$ $(15 \%)$, and LP owns the remaining $\$ 340(85 \%){ }^{140}$ During Year 3, GP earns an investment return of $\$ 13$ and the government earns an investment return of $\$ 7$ on the additional contributions. At the end of Year 3, P pays

137. The $\$ 60$ of investment return in Year 3 can be viewed equivalently as GP's $15 \%$ proportionate share based on relative capital accounts $(\$ 60 / \$ 400)$ of the partnership's total profits $(\$ 400)$; alternatively, the $\$ 60$ of investment return can be viewed as twice GP's capital account balance at the end of Year $2(\$ 60)$, since the partnership's assets double in value each year. See infra note 142 and accompanying text.

138. See, e.g., David Elkins \& Christopher H. Hanna, Taxation of Supernormal Returns, 62 TAX LAW. 93, 95-97 (2009) (exploring the "partnership view" under a cash-flow consumption tax).

139. Each partner's invested capital and return on invested capital would be as follows:

\begin{tabular}{|l|l|l|}
\hline & $\begin{array}{l}\text { Capital Contribution } \\
\text { (End YR 1) }\end{array}$ & $\begin{array}{l}\text { Return on Capital } \\
\text { (YR 2 and YR 3) }\end{array}$ \\
\hline GP & 13 & $13+26$ \\
\hline Gov & 7 & $7+14$ \\
\hline Total & 20 & 60 \\
\hline
\end{tabular}

140. GP's implicit Year 2 salary of $\$ 20$ is equal to GP's entire Year 2 profits share of $\$ 40(20 \%$ x $\$ 200$ profit) less the $\$ 20$ imputed investment return for Year $2(10 \% \times$ x $\$ 200$ profit). 
implicit salary of $\$ 20$ to GP and immediately liquidates. ${ }^{141}$ Upon liquidation of P, GP and the government are entitled to the amounts in their respective capital accounts ( $\$ 140$ total, or $20 \%$ of $\$ 700$ increase in P's value) and LP receives the remainder $(\$ 660) .{ }^{142}$

Now, it is possible to compare the results under the cash salary reinvestment plan and an economically equivalent option. If GP and the government are treated as co-investors, GP receives tax free the amount in his capital account $(\$ 91)$ and the government receives the amount in its capital account (\$49). If GP instead held a European option and GP's compensatory return were taxed on exercise, the after-tax consequences to GP and the government would be identical. ${ }^{143}$ The amount in the government's capital account represents the future value of the deferred tax on the compensation component of GP's return. The $\$ 49$ of tax on GP's salary does not yet reflect tax owed on GP's investment return. The cumulative investment return to GP is $\$ 52(\$ 39+\$ 13)$ and the cumulative investment return to the government is $\$ 28(\$ 21+\$ 7)$. The tax on GP's investment return is $\$ 7.80(\$ 52 \times 0.15)$, i.e., $\$ 80 \times 0.0975 .^{144}$ The government's investment return $(\$ 28)$ is not a tax; instead, it is merely the government's return as a co-investor. ${ }^{145}$ The total investment return $(\$ 80)$ is the sum of the investment return on each co-investor's capital account.

141. GP's implicit Year 3 salary of $\$ 20$ is equal to GP's entire Year 3 profits share of $\$ 80$ (20\% x $\$ 400$ profit) less the $\$ 60$ imputed investment return for Year 3 (15\% x $\$ 400$ profit).

142. The partners' respective capital accounts are as follows:

\begin{tabular}{|c|c|c|c|c|}
\hline & \multicolumn{4}{|c|}{ Capital Accounts } \\
\hline & GP & Gov & GP/Gov & LP \\
\hline Initial & 0 & 0 & 0 & 100 \\
\hline End YR 1 & 13 & 7 & 20 & 180 \\
\hline End YR 2 & 39 & 21 & 60 & 340 \\
\hline End YR 3 & 91 & 49 & 140 & 660 \\
\hline
\end{tabular}

143. On exercise of the option, GP would receive $\$ 140(20 \% \times$ x $\$ 700$ increase in P's value) and would owe tax of $\$ 49$ (35\% x \$140), leaving GP with $\$ 91$ ( $\$ 140$ less $\$ 49$ tax).

144. The tax of $\$ 7.80$ on GP's portion of the investment return is equal to the tax on the entire investment return $(\$ 80)$ times 0.0975 , i.e., $0.15 \times(1-0.35)$; it is assumed that the investment return is taxed entirely at the end of Year 3. See Walker, supra note 5, at 762-63 (proposing special surtax on the gain component of equity compensation payouts at the special rate of $9.75 \%$ to replicate the effect of taxation at the date of grant). Proposed $\S 710$ could be viewed as imposing "surrogate taxation" of the investment return attributable to GP's reinvested implicit salary when LP is tax exempt. See Daniel I. Halperin, Interest in Disguise: Taxing the Time Value of Money, 95 YALE L.J. 506, 523 (1986) (explaining substitute tax approach). Yet, Prop. $§ 710$ applies whether or not LP is tax exempt.

145. See Elkins \& Hanna, supra note 138, at 96. 
To summarize, the cash salary reinvestment plan divides GP's return into two components: a compensatory component and an investment component. The investment component consists of the yield (at P's rate of return) on GP's reinvested salary. GP's total compensatory return (\$140) is taxed as ordinary income under both the cash reinvestment plan and option alternative. The only difference is that, under the cash salary reinvestment plan, the investment return on GP's reinvested salary is taxed to GP (at capital gain rates), thereby curtailing the benefit of yield exemption. By opting out of $\S 710$, however, GP can restore yield exemption if he receives an option rather than a profits interest. Under the option alternative, all of the investment return is taxed at LP's zero rate, leaving GP in the same position as an employee who defers compensation through a tax-exempt employer.

The co-investment analogy illustrates that if $\S 710$ operated according to its goals, it would tax GP on the discounted present value of his compensation income, while imputing an investment return (taxed as capital gain) on GP's reinvested salary. In present-value terms, current and deferred taxation of the compensation component of GP's return should be equivalent. ${ }^{146}$ Since the tax is imposed on the augmented payout, deferring taxation of GP's implicit salary does not necessarily leave the government worse off: the "loan" from the government is "repaid at an interest rate reflecting the taxpayer's rate of return on investment." 147 Under $\S 710$, a portion of the investment return is shifted from LP to GP (and taxed at GP's rate); as a result, the government collects a capital gain tax on the investment return on reinvested salary that it would otherwise forego if the parties had structured the transaction as a European option. The "extra" capital gain tax is simply the tax on the investment return on GP's reinvested salary which would compound tax free if GP were permitted to invest through LP (GP's tax-exempt employer). ${ }^{148}$ Since this type of jointtax arbitrage occurs whenever compensation is deferred and the employer is tax exempt, however, it is not clear that $\S 710$ is needed to address this

146. By analogy to a traditional IRA, deferring the tax on GP's salary and taxing the accumulated amount is equivalent to taxing the initial salary and exempting the investment return. See William D. Andrews, A Consumption-Type or Cash Flow Personal Income Tax, 87 Harv. L. REV. 1113, 1126 (1974) ("[D]eferring the tax is the equivalent of imposing the tax initially, but exempting any subsequent profit due to continued investment of what is left after payment of the tax.”); Walker, supra note 5, at 711.

147. Halperin, supra note 144, at 532; id. at 533 (noting that the government "does not necessarily lose when it 'lends' by deferring inclusion of an employee's income" if the private parties earn a higher rate of return).

148. See id. at 539-50 (suggesting that the tax advantages of nonqualified deferred compensation could be significantly curtailed by taxing currently — at the employee's rates the investment income earned on the deferred compensation). 
problem. ${ }^{149}$

If one objects to GP's ability to obtain IRA-like yield exemption when LP is tax-exempt, then the problem is not necessarily cured by $\S 710$ which merely encourages a shift from profits treatment to option treatment. Once again, the problem of joint-tax arbitrage results not from a flaw in the treatment of profits interests but rather from GP's ability to exploit LP's tax-exempt status. If LP were taxable, option treatment would not result in any joint-tax advantage (or disadvantage) because investment return would be fully taxed. Whether the investment return is taxed at LP's rate or GP's rate is a matter of indifference if both parties are same taxed, since someone must always be taxed on the investment return.

Example (4) ignores all of the problems of valuing P's illiquid assets, the timing of gain accrual, the reasonableness of returns to qualified capital, and the passthrough of losses. As a partner, GP benefits from the ability to use losses that are worthless to LP. In addition, GP's share of subsequent losses is treated as ordinary to the extent of prior ordinary income taxed to GP under $\S 710$. Once the passthrough of losses is taken into account, the parties' joint-tax burden may be significantly less under $\S$ 710 than if GP held a European option.

Example (5)-Loss Passthrough. The facts are the same as in Example (4), except that the operation of $\mathrm{P}$ is extended to include an additional year (Year 4) in which $P$ realizes a loss of $\$ 300$, allocated $\$ 60$ to GP and $\$ 240$ to LP. Overall, P realizes a net gain of $\$ 400$ (\$700 gain less $\$ 300$ loss). If $\mathrm{P}$ liquidates at the end of Year 4, GP earns carry of $\$ 80(20 \%$ $\mathrm{x} \$ 400$ net gain). GP's share of the capital loss is likely treated as an ordinary loss and allowed to the extent that such loss does not exceed the excess (if any) of "aggregate net income with respect to" GP's service interest for all prior years over "the aggregate net loss with respect to such interest not disallowed [under $\S 710$ ] for all prior partnership taxable years." $" 150$ If the capital loss of $\$ 60$ is treated as an ordinary loss that offsets GP's ordinary income from all prior years $(\$ 60)$, GP is taxed on net capital gain of $\$ 80 .{ }^{151}$ Given the lack of any mechanism for separating GP's

149. In the corporate context, a taxable employer can effectively invest tax free on behalf of an employee by investing in its own securities and holding the stock for the employee's benefit — rather than issuing the stock directly to the employee; the employer's gain on its own stock is nontaxable under $\S 1032$. See id. at 540.

150. See Prop. § 710(a)(2)(A).

151. GP's overall return is as follows:

\begin{tabular}{|l|l|l|l|l|}
\hline & Y1 & YR2 & YR3 & YR4 \\
\hline OI & 20 & 20 & 20 & $(60)$ \\
\hline CG & & 20 & 60 & \\
\hline
\end{tabular}


service interest and GP's qualified capital interest, it seems likely that GP is taxed on net capital gain of $\$ 80$, since (ordinary) losses offset (ordinary) income. $^{152}$

By contrast, if GP held a European option, GP would recognize $\$ 80$ of ordinary income (20\% of $\$ 400$ net increase in P's value) at the end of Year 4. Since GP performs the identical services, GP should be taxed equivalently in both situations; otherwise, LP and GP derive a joint-tax benefit from structuring the transaction formally as a profits interest rather than a European option. If $\mathrm{P}$ is sufficiently profitable on a net basis, GP will eventually receive compensation measured by the amount of P's total profits (not a reduced percentage of P's profits augmented by an imputed investment return on GP's reinvested salary). Despite the carefullycontrived optics, the capital credited to GP can be viewed as remaining LP's capital on which LP is entitled to an investment return. If the transaction were held open, GP's entire share of profits would be taxed as ordinary income (not as a mix of ordinary income and capital gain). ${ }^{153}$ Even if some portion of GP's return is from earned capital, the "best compromise" may be to treat GP's entire profits interest as ordinary income. ${ }^{154}$ Alternatively, if GP were willing to forego current allocation of losses, GP's profits share could be structured as a European option (or vesting capital interest).

\section{Shortcomings of Capital Accounts}

When previously taxed implicit salary is reinvested in the partnership, a mechanism is needed to track the separate labor and capital components of the service provider's future return. Some reformers have suggested that the capital account system would permit tracking of a service partner's compensatory and investment return over the life of the

152. If the loss of $\$ 60$ is instead treated as incurred "with respect to" GP's qualified capital interest, it would offset an equivalent amount of capital gain (rather than $\$ 60$ of ordinary income), leaving GP with ordinary income of $\$ 60$ and capital gain of $\$ 20$ overall. $C f$. Scharfstein, supra note 136, at 154 (suggesting that GP should lose the ability to claim an ordinary loss if GP's retained earnings are treated as invested capital).

153. GP would be treated essentially as annually exercising a stock appreciation right (SAR) as profits are allocated. See Senate Hearings, supra note 1 (Statement of Charles I. Kingson, July 31, 2007) (analogizing profits interest to a series of SARs).

154. See Weisbach, supra note 14, at $755 \mathrm{n} .91$ (noting that, even if a portion of GP's return "is capital income in the sense that it represents returns that are left in the business rather than taken out each year as salary," the "best compromise [may be] to treat it all as labor income exactly as we do in the case of restricted stock or nonqualified options"). 
partnership. ${ }^{155}$ The obvious difficulty, however, is that the elaborate capital account system was never intended to serve this function. Instead, it is intended merely to police allocations among partners that seek to minimize joint taxes. Since partnerships are not required to maintain capital accounts in accordance with the elaborate rules of $\S 704(\mathrm{~b})$, many (perhaps most) do not. The "intellectual revolution" built around capital-account analysis remains highly imperfect and it would require a tremendous infusion of government resources to ensure even minimally adequate compliance. ${ }^{156}$

As the experience with the $\S$ 704(b) regulations amply demonstrates, the ability of sophisticated planners to abuse even wellcrafted rules should not be underestimated. The capital account rules are not designed to police valuation abuses that $\S 710$ would invite. ${ }^{157}$ Jointly, LP and GP will often have a common incentive to overstate the capital component (and understate the compensation component) of GP's return. It is well understood, under current law, that "[a]sset valuation is the Achilles heel of the system of capital accounts analysis." 158 Without adversity of interests, it is impossible to police self-serving valuations intended to understate or overstate asset values. The partnership tax bar has suggested that future regulations should permit bookups (or bookdowns) of invested capital, expanding opportunities for misvaluation; requiring mandatory gain recognition on a revaluation to "temper the incentive to revalue" does not seem a practicable response to this problem. ${ }^{159}$

In assessing the merits of the $\S 710$ approach, one should focus on the existing passthrough system, which bears little resemblance to the ideal

155. See Senate Hearings, supra note 1 (Statement of Mark P. Gergen, July 11, 2007).

156. See Lawrence Lokken, As the World of Partnership Taxation Turns, 56 SMU L. REV. 365, 369 (2003) (suggesting that the "intellectual revolution [in capital account analysis] will not become a revolution in the practical reality of partnership taxation"); $c f$. Mark P. Gergen, The End of the Revolution in Partnership Tax?, 56 SMU L. Rev. 343 (2003).

157. To address the problem of special allocations, a recent ALI project considered but rejected the notion of reforming capital accounts to take into account time value of money concerns and proper adjustments for risk. See generally George K. Yin \& David J. Shakow, american Law Institute, Federal income Taxation Project, Taxation of Private BUSINESS ENTERPRISES: REPORTERS' STUDY (1999).

158. Gergen, supra note 156 , at 362 . By rendering Subchapter K even more complex and opaque, Prop. $\S 710$ may undermine the prospects of more thoroughgoing reform while exacerbating the need for such reform.

159. Gergen, supra note 12 , at 146 (suggesting immediate gain recognition on a revaluation as a "simple way to temper the incentive to revalue"); $c f$. NYSBA Report, supra note 11 , at 5 (inviting future regulatory guidance concerning "adjustment[s] to existing invested capital to reflect any unrealized gain or loss related to such invested capital" on a subsequent contribution or distribution). The current rules explicitly permit a revaluation of partnership property only when the parties can realistically be expected to have "sufficiently adverse interests." See Treas. Reg. § 1.704-1(b)(2)(iv)(h) (as amended in 2008). 
envisioned by some reformers. Within the current system of flexible allocations backstopped by an array of anti-abuse rules, imputing a reasonable return on reinvested salary based on capital account balances may merely mask the fundamentally insoluble problem of separating returns to labor and investment. ${ }^{160}$ Without a baseline of proportionate allocations, it is impossible to tell whether an allocation is disproportionate. ${ }^{161}$ Special allocations are permitted based on the notion that partners should be free to allocate items among themselves in a manner that matches the flexibility of their business arrangement. The underlying presumption is that such flexibility is tolerable because the partners are likely to have adverse interests. The notion of offsetting benefits and detriments - the justification for allowing flexible allocations under Subchapter K-is the antithesis of the $\S 710$ approach which alters only the tax consequences to service partners.

Congress has barely begun to consider the myriad challenges of integrating $\S 710$ with the already excessively intricate provisions of partnership tax. For example, Congress would need to coordinate $\S 710$ with the collapsible partnership rules of $\S 751$ governing sales of interests and disproportionate distributions. ${ }^{162}$ When a service partner's interest is sold, it would be necessary to bifurcate the amount realized between the ordinary-income and capital-gain components even though gain at the partnership level consists solely of capital gain. ${ }^{163}$ Except on sale of an interest, Congress seems quite oblivious to the potential shifting of ordinary income and capital gain with respect to the service partner's interest. ${ }^{164}$ While $\S 710$ refers expressly to $\S 751$ (a) governing sales of partnership interests, it ignores $\S 751(\mathrm{~b})$, the companion provision governing

160. See David A. Weisbach, Professor Says Carried Interest Legislation is Misguided, 116 TAX NOTES 505, 510 (2007) ("The Levin bill simply glosses over [the] central problem, hiding its complexities behind a rule that allocations must be reasonable.").

161. See Weisbach, supra note 14, at 756 ("There is no way to draft laws or regulations that identify any potential service component to the capital allocation."); id. (noting that challenges by the Service would be expensive and time-consuming, with the Service having "little chance of winning except in egregious cases"); see also Rosenzweig, supra note 23, at 729 (discounting the possibility that "adding the additional complexities of the partnership accounting rules into the mix will lead to a more rational or implementable solution" to the problem of blended returns to labor and capital).

162. See I.R.C. § 751(a) (2009) (sales), § 751(b) (2009) (disproportionate distributions). A disposition of a service partner's interest would trigger recognition of ordinary income notwithstanding otherwise applicable provisions. See Prop. § 710(b)(1).

163. See Gergen, supra note 12, at 146 ("It is not clear how a [service partner's] overall book gain should be spread across a mix of gain and loss assets. And so on.").

164. There would clearly be an incentive to specially allocate ordinary income (or shortterm capital gain) to the service partner's carried interest. See ABA Comments, supra note 11, at 21; see also NYSBA Report, supra note 11, at 59 n.151. 
distributions of partnership property. ${ }^{165}$ Since 1954, a central tenet of Subchapter K has been the need to prevent shifting of capital gain and ordinary income among partners. ${ }^{166}$ There is no justification for allowing such shifting within the return of a single partner (GP), often with no detriment to the other partners. Indeed, $\S 710$ would likely provide an opportunity for partnership tax bar to demand repeal of $\S 751(\mathrm{~b})$.

\section{CONCLUSION}

In response to the partnership tax bar's recommendations, the current version of carried interest legislation would expand the concept of qualified capital and revise $\S 83$ to entrench an unwarranted valuation subsidy for partnership profits interest. The underlying notion is that $\S 710$ is a substitute for the generally applicable rules of $\S 83$ governing transfers of property for services. By contrast, this Article suggests that $\S 710$ will often understate the compensation component of a service provider's return by taxing less than all of a profits interest as ordinary income and providing an incentive to the parties to overstate the capital component attributable to earned capital. By amending $\S 83$ to codify a pro-taxpayer valuation rule for profits interests (zero value), the carried interest legislation affords separate but not equal treatment of partnership deferred equity compensation. $^{167}$

Even though academic commentators have sought to clarify the joint-tax benefits of carried interest arrangements, the current legislation pursues a solution premised narrowly on the one-sided advantage to GP. The pragmatic argument in favor of $\S 710$ is that taxing at least some portion of GP's compensation as ordinary income represents an adequate tradeoff for preserving the current favorable treatment of LPs. ${ }^{168}$ The

165. This omission is perhaps not surprising since reformers conspicuously failed to mention $\S 751(b)$. See, e.g., Senate Hearings, supra note 1 (Statement of Mark P. Gergen, July 11,2007 ) (referring only to $\S 751(a)$ ). Cf. Prop. $\S 710(b)(4)$ (distributions of appreciated property "with respect to" a service partner's interest).

166. While conceding the need for $\S 751(\mathrm{a})$, the partnership tax bar generally views $\S$ 751(b) as too complex and ripe for repeal. See generally Karen C. Burke, Origins and Evolution of $\$ 751(b), 60$ TAX LAw. 247 (2007) (discussing 1954 reform and Professor William D. Andrews' more recent proposals).

167. While Prop. $\S 710$ is more favorable to service providers than McKee's 1977 proposal, the latter predated the capital account regime of which McKee was the architect. See supra notes 108-11 and accompanying text; see also Abrams, supra note 2, at 197 ("[M]any have come before, with essentially the same arguments leading to the same proposed solutions.”).

168. If one considers hedge funds, the "tradeoff" may be more apparent than real. Since GP's profits (as hedge fund manager) consist mostly of short-term capital gain (already 
recharacterization approach is neither simple nor straightforward: it will often yield illogical results and inevitably collide with other provisions of Subchapter K. Having helped to identify important defects in the current proposal, the partnership tax bar seems increasingly reconciled to $\S 710$ 's recharacterization approach should reform go forward. Nevertheless, a "workable" solution from the bar's perspective may be quite different from a coherent or administrable reform. Indeed, the current proposal's unintended effects, electivity, and lack of transparency illustrate why it is essential to consider tradeoffs and implementation from a joint-tax perspective. $^{169}$

While one commentator has dismissed the proposed reform as "a bad idea badly executed" that deserves to fail, the dynamics of carried interest legislation are considerably more complex. ${ }^{170}$ Having confidently identified the underlying problem as one-sided conversion and deferral, well-intentioned reformers suggested the purportedly simple solution of recharacterizing a service partner's share of partnership income. Unable to craft workable rules implementing this simple solution, Congress turned to the partnership tax bar which recommended changes that would complicate yet further the existing partnership rules, without adequately addressing potential joint-tax arbitrage. Indeed, under the Administration's budget proposal, the carried interest legislation could potentially affect service partners in all partnerships, inflicting considerable damage on routine business arrangements that pose little or no potential for abuse. Rather than enact complex legislation of uncertain scope, Congress should consider delegating authority to Treasury under existing provisions to address capital-gain conversion and limit advantageous trading of tax characteristics.

taxed essentially like ordinary income), Prop. $§ 710$ would affect mainly the character of gain (ordinary or capital) on sale of a hedge fund manager's interest. Cf. Kingson, Carried Interests: An Outdated Term?, supra note 70, at 127 (current case law refutes the claim that sale of "contracts to manage [a] hedge fund" results in capital gain).

169. From a "global" perspective, it is important to consider the government's limited resources to enforce any solution without diverting attention from other partnership abuses. See Walker, supra note 5, at 699 n.10 (adopting the term "global" to describe the employeremployee joint-tax perspective and specifically referring to "the third actor in this play, the Treasury").

170. Abrams, supra note 2, at 227. 